\title{
Fire Department Emergency Response
}

by

A. Blanchard

Westinghouse Savannah River Company

Savannah River Site

Aiken, South Carolina 29808

K. Bell

J. Kelly

J. Hudson

\section{MASTER,}

\section{DISTRIBUTION OF THIS DOCUMENT IS UNLMTTED}

This paper was prepared in connection with work done under the above contract number with the U.S.

Department of Energy. By acceptance of this paper, the publisher and/or recipient acknowledges the U.S. Government's right to retain a nonexclusive, royalty-free license in and to any copyright covering this paper, along with the right to reproduce and to authorize others to reproduce all or part of the copyrighted paper. 


\section{DISCLAIMER}

This report was prepared as an account of work sponsored by an agency of the United States Government. Neither the United States Government nor any agency thereof, nor any of their employees, makes any warranty, express or implied, or assumes any legal liability or responsibility for the accuracy, completeness, or usefulness of any information, apparatus, product, or process disclosed, or represents that its use would not infringe privately owned rights. Reference herein to any specific commercial product, process, or service by trade name, trademark, manufacturer, or otherwise does not necessarily constitute or imply its endorsement, recommendation, or favoring by the United States Government or any agency thereof. The views and opinions of authors expressed herein do not necessarily state or reflect those of the United States Government or any agency thereof.

This report has been reproduced directly from the best available copy.

Available to DOE and DOE contractors from the Office of Scientific and Technical Information, P. O. Box 62, Oak Ridge, TN 37831; prices available from (423) 576-8401.

Available to the public from the National Technical Information Service, U. S. Department of Commerce, 5285 Port Royal Road, Springfield, VA 22161. 


\section{DISCLAIMER}

Portions of this document may be illegible electronic image products. Images are produced from the best available original document. 


\section{FIRE DEPARTMENT EMERGENCY RESPONSE}

\section{BASELINE NEEDS ASSESSMENT}

Rev. 2

September 15, 1997

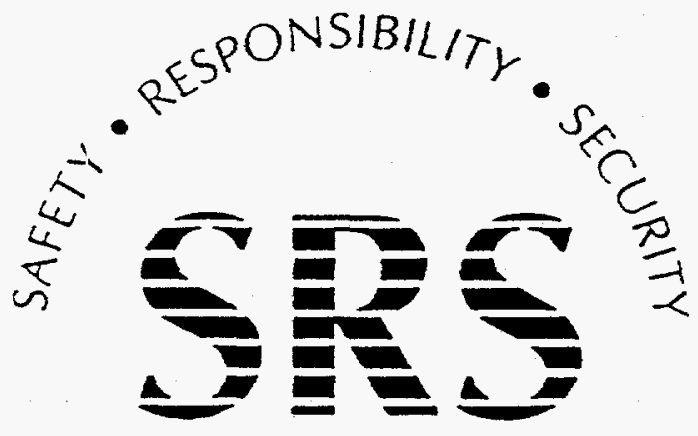

SAVANNAH RIVER SITE

\section{Emergency Services Department} Technical Services Division W'estinghouse Savannah River Company Savannah River Site

Aiken, SC 29802

(803) $557-6679$ 
SIGNATURE PAGE

Authors:

Vemeth \& Bell L

Kenneth L. Bell

Savannah River Site Fire Department

With an T. Elliot

William T. Elliott

Savannah River Site Fire Department

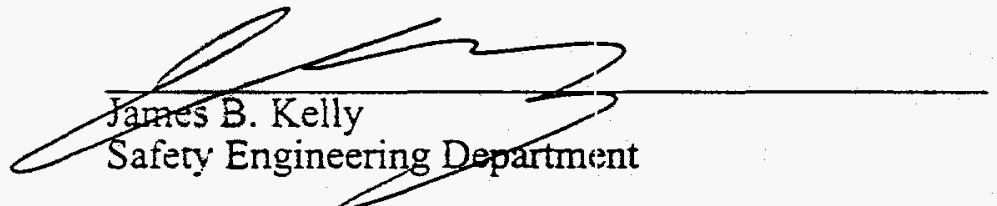

Roles d. Still

Roper G. Still

Savannah River Site Fire Department

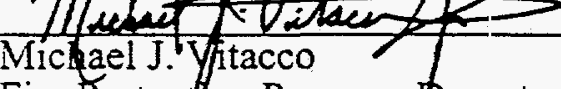

Fire Protect lon Program Department

Approvers:

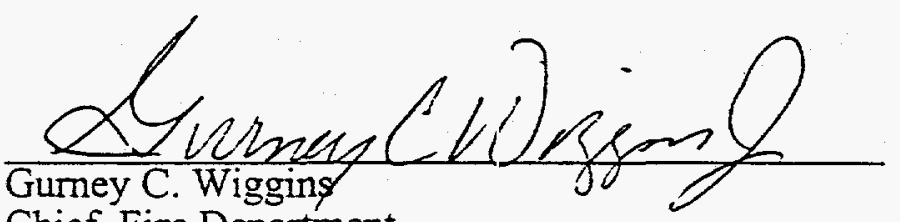

Chief, Fire Department

Pichual E Qebuok

Manager, Emergency Services Department

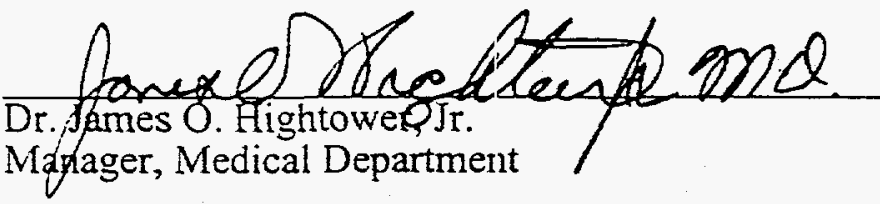

$\frac{9 / 24 / 97}{\text { Date }}$

$\frac{9 / 17 / 97}{\text { Date }}$

$\frac{9 / 24 / 97}{\text { Date }}$

$\frac{9 / 17 / 97}{\text { Date }}$

$\frac{9-30-97}{\text { Date }}$

$\frac{9 / 24 / 97}{\text { Date }}$

$\frac{9 / 29 / 97}{\text { Date }}$

23 beat 97 


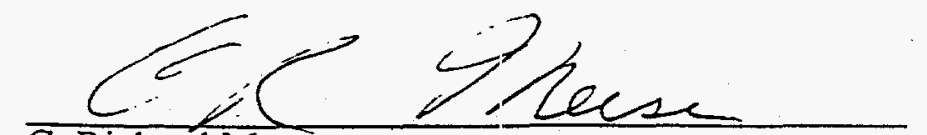

C. Richard Meuse

Manager, Fire Protection Program Department

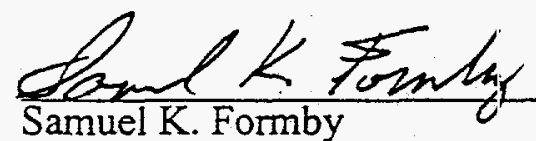

Samuel K. Formby

Deputy Manager, Technical Services Division
$9 / 30 / 97$

Date

$\frac{9 / 30 / 97}{\text { Date }}$

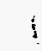




\section{TABLE OF CONTENTS}

1.0 Executive Summary

2.0 Introduction. 3

3.0 Site Hazard Identification ...................................................................4

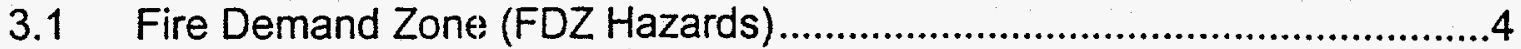

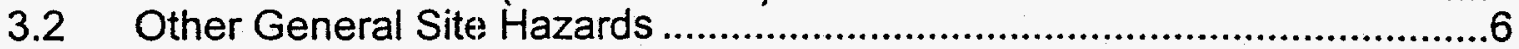

3.2.1 Potential Transportation Hazardous Material Incidents ..............................6

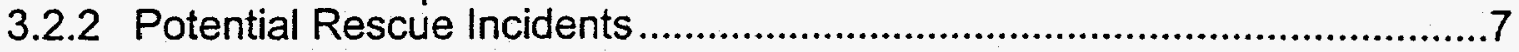

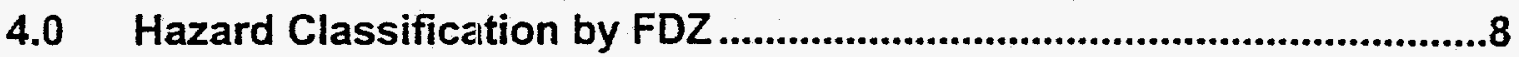

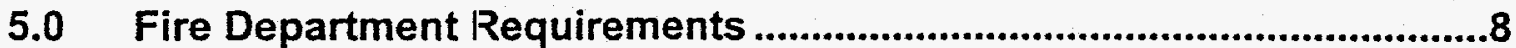

$5.1 \quad$ Fire Suppression Incidents Staffing Analysis .....................................10

5.1 .1 Background .........................................................................................

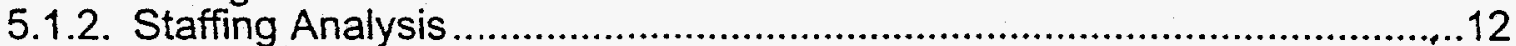

5.1.2.1 Baseline Staffing ...............................................................12

5.1.2.2 Facility Fires Which Exceed Baseline Staffing.............................14

5.2 Emergency Medical Service Staffing Analysis..........................................20

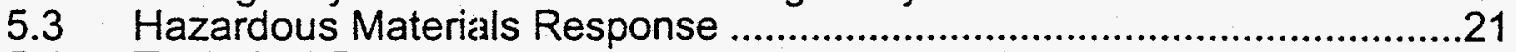

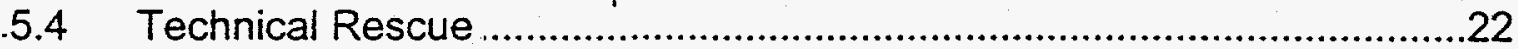

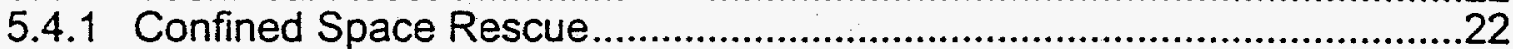

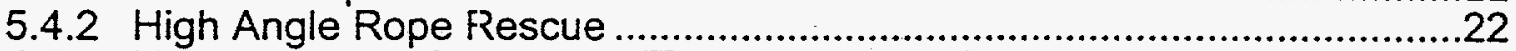

5.4.3 Heavy Rescue Operations (Trench and Building Collapse Rescue) ........23

5.4.4 Vehicle Extrication ......................................................................24

5.5 Simultaneous/Sigrificant Incident Supplemental Staffing Protocol ..........24

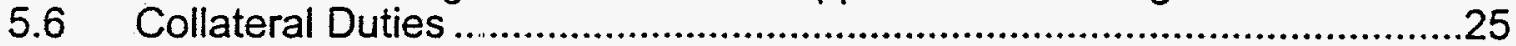

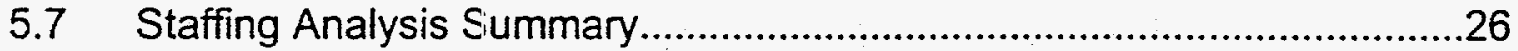

6.0 Fire Department Apparatus/Equipment Requirements .....................27

6.1 Current Assessment of Existing Apparatus .........................................27

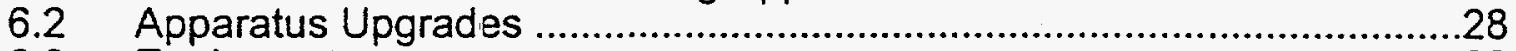

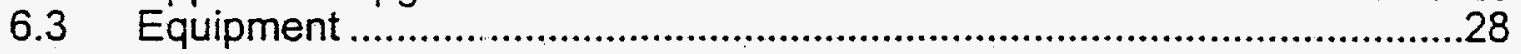

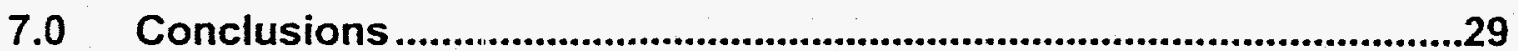

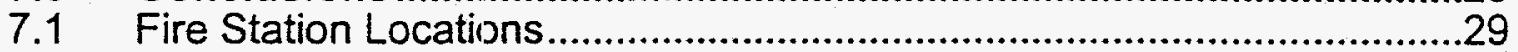

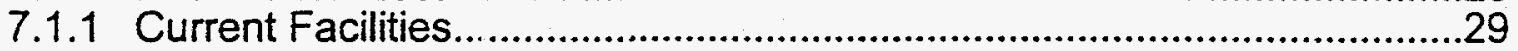

7.1.2 Recommendations for Fire Station Replacements .................................30

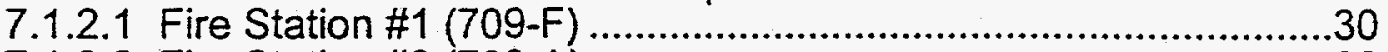

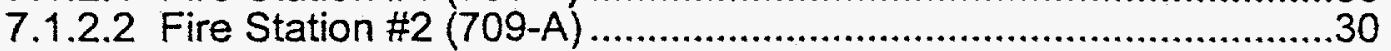

7.1.3 Fire Station Location and Response Time Summary ..............................30

7.2 Staffing Levels ...........................................................................................

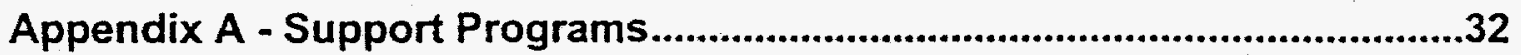

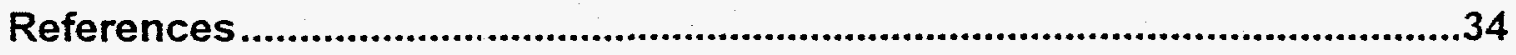




\subsection{EXECUTIVE SUMMARY}

In 1995 the SRS Fire Department published the initial Operations Basis Document (OBD). This document was one of the first of its kind in the DOE complex and was widely distributed and reviewed. This plan described a multi-mission Fire Department which provided fire, emergency medical, hazardous material spill, and technical rescue services.

In the intervening two years since the original OBD was published, a new DOE Order (420.1) has been issued which better defines the standards for such documents. The DOE Order 420.1 became an SR.S requirement on 12/26/96 with DOE-SR approval of the Functional Area 12, "Fire Protection" of the Site/Requirements Identification Document (S/RID). In addition, new engineering analysis and operational experience require a reexamination of service needs and response capabilities.

The principal change in this document from the 1995 publication is the definition of the fire hazard. Separate DOE and WSRC teams have provided input that the DOD $10 \%$ involvement fire with minimum NFPA compliance task assignments to such a fire are not justified in all cases. This baseline needs assessment determined that an increase in the minimum staffing for the fire response from 14 specified in 1995 to 18 was necessary and became effective on June 16, 1997. The biggest change in these two analyses is in the -area of minimum shift staffing caused by the WSRC medical control requirement of an EMS unit at the incident as well as a second EMS unit being available for a simultaneous independent incident.

It must be emphasized that, for the fire department, the responsibilities, performance elements, and required resources are minimums that were developed based on assumptions regarding the potential nature of site emergencies.

There is also a recognized potential for the occurrence of a second medical event concurrent with a major site emergency. Consequently, this document attempts to realistically identify the resources necessary to respond to a fire and simultaneous medical emergency. However, the fire department has only a limited capacity (call back, limited mutual aid, and transition from "offensive" to "defensive" tactics) to effectively deal with such circumstances. To the extent that the fire department is not provided with additional resources beyond existing capabilities of responding to concurrent emergencies, the DOE is assuming some risk. This assumption of risk is considered reasonable given the fire loss record and extent of fire prevention activities and fixed fire protection on site. Note that there is a significant potential increase in risk in the future when decontamination and decommissioning (D\&D) activities increase or missions change and that this baseline document must be reassessed at that time.

The report which follows summarizes the hazards posed by a representative sample of nuclear and highly populated non-nuclear facilities at SRS which require a Fire Department response. Based on these hazards the required levels of service for each functional area are analyzed. There is also a description of facilities, equipment, training and offsite community involvement.

The operating basis set forth in this document provides cost effective emergency response capability for the service areas of the SRS Fire Department - e.g. fire suppression, emergency medical, hazardous material and technical rescue response. Guidance was adopted from the Uniform Building Code, Uniform Fire Code, National Fire Protection 
Association (NFPA) Standards, Implementation Guide for Use with DOE Orders 420.1 and 440.1, Section 6.0 - Fire Department Operations, and the U.S. Occupational Safety and Health Administration. The basis for operation is predicated upon the following considerations:

a. Assumption of risk commensurate with SRS emergency response incident experience and standard industry practice.

b. Assumption that only one baseline emergency incident will be in progress at any one time for SRS operations and an EMS unit will be available for a simultaneous emergency medical incident.

c. That the Fire Departrnent meets all NFPA Standards for safe and effective response.

d. That fire protection features of construction and installed fire protection systems will be maintained to function as designed in the event of a fire.

Upon acceptance of this Baseline Needs Assessment, an implementation plan must be developed describing how the Fire Department will organize and staff itself to meet the identified needs. The inplementation must include drills to validate the Fire Department's capabilities, in particular, response times, training, and adequacy of .staffing. The SRS Fire Department must meet response time requirements to the site facilities with adequate resources and equipment to respond to prescribed events. Site emergency incidents exceeding the planning basis resource requirements will be addressed through call back procedures and reciprocal aid protocols established by the SRSFD. 


\subsection{INTRODUCTION}

The Savannah River Site (SRS) has a Department of Energy (DOE) sponsored fire department that protects approximately 5,600 buildings located on 310 square miles. The site has a wide variety of nuclear production facilities that include chemical processing facilities, machine shops, nactive production reactors, nuclear material storage and processing, and laboratories. The geography of SRS is dominated by woodlands that are managed by the US Forest Service (USFS). The DOE operating facilities comprise less than 10 percent of the total site area. Industrial facilities are grouped into areas that are spaced approximately 3 miles apart.

At SRS the responsibilities of the Fire Department response organization include four service areas: emergency medical, fire, hazardous material, and rescue response for the entire site as well as collateral functions including the maintenance and inspection of some fire suppression components. The SRSFD also supports our neighboring community by providing mutual aid. To provide response capabilities in each service area, the Fire Department must provide timely response to any emergency with adequate forces and appropriate equipment to mitigate the event. Therefore, fire station locations, availability of trained response personnel, equipment and apparatus must be maintained based on the potential emergencies for the site. There is a correlation between the site's potential emergencies and the missions of the facilities.

In the post Cold-War climate, SRS missions are continually changing. An overview of current missions and anticipated near-term mission changes are presented in Table 2.1 For detailed current information, the reader is encouraged to refer to the "Programmatic Guidance for Fiscal Year 1998", which is readily available on Shrine.

TABLE 2.1

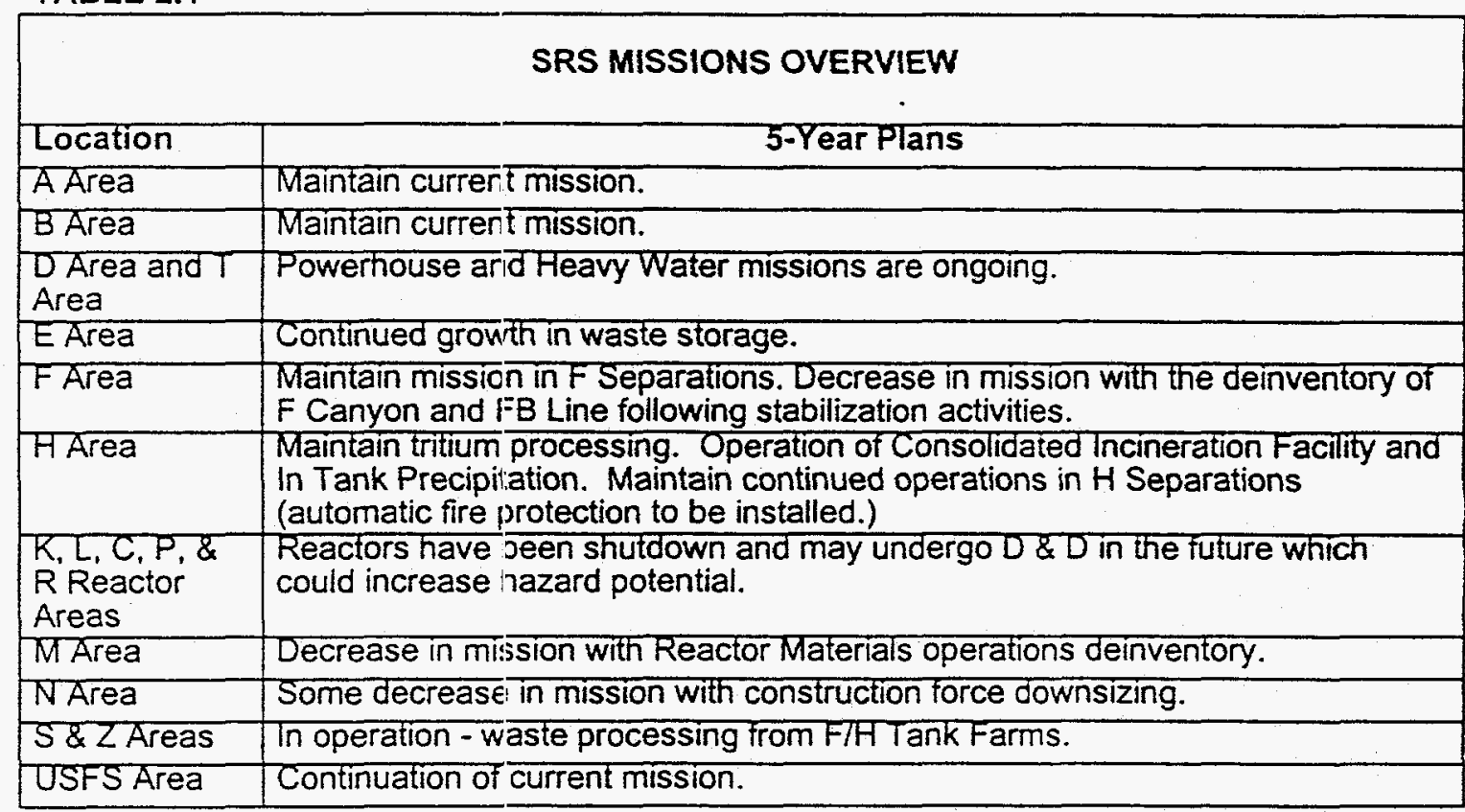


The mission changes for some facilities at SRS generally imply that the need for Fire Department response is affected. However, this does not necessarily imply that the emergency response needs for those areas decrease at the rate of mission decrease. The hazards maintained in each area, the types of activities that occur within the area, and changes to the number of personnel in each area will drive the Fire Department's response needs.

\subsection{SITE HAZARD IDENTIFICATION}

\subsection{Fire Demand Zone (FDZ) Hazards}

SRS Fire Department response planning is performed by geographically grouping the facilities located across the site into response planning areas and analyzing the hazard classification of each area. The Fire Department response planning areas are called Fire Demand Zones (FDZs). The FDZs and their primary radiological and chemical hazards are described in Table 3.1, Pjimary Hazards.

TABLE 3.1

\begin{tabular}{|c|c|c|c|}
\hline \multicolumn{4}{|c|}{ PRIMARYAAZARDS } \\
\hline FDZ & DESCRIPTION & $\begin{array}{l}\text { RADIOLOGICAL } \\
\text { HAZARDS }\end{array}$ & $\begin{array}{l}\text { CHEMICAL } \\
\text { HAZARDS }\end{array}$ \\
\hline A Area & $\begin{array}{l}\text { Administrative buildings, } \\
\text { maintenance and repair facilities, } \\
\text { warehouses for } \text { txcess materials, } \\
\text { coal fired power house, satellite } \\
\text { bulk fuel storage area for } \\
\text { gasoline and die:sel fuel and the } \\
\text { Savannah River Technology } \\
\text { Center (SRTC). }\end{array}$ & $\begin{array}{l}\text { High level radioactive } \\
\text { materials with criticality } \\
\text { potential, uranium and } \\
\text { plutonium. (SRTC only) }\end{array}$ & $\begin{array}{l}\text { Laboratory reagents, } \\
\text { compressed and } \\
\text { flammable gases, } \\
\text { hydrocarbon fuels, acids } \\
\text { and bases of significant } \\
\text { quantity in storage } \\
\text { warehouses. }\end{array}$ \\
\hline B Area & $\begin{array}{l}\text { Administration buitidings, repair } \\
\text { and maintenance! facilities, } \\
\text { heliport, environrnental analytical } \\
\text { labs, warehouses, waste water } \\
\text { treatment facility and WSI } \\
\text { ammunition storage bunker. }\end{array}$ & $\begin{array}{l}\text { Powdered, depleted } \\
\text { Uranium storage in } \\
\text { building } 772-7 \mathrm{~B} \text {. }\end{array}$ & $\begin{array}{l}\text { Sulfur dioxide in } \\
\text { nitrogen, caustic } \\
\text { materials and various } \\
\text { cleaning compounds } \\
\text { and flammable liquids. }\end{array}$ \\
\hline CArea & $\begin{array}{l}\text { CReactor (cold shutdown status) } \\
\text { facilities are utilized as heavy } \\
\text { water storage facilities. } \\
\text { Structures include: maintenance } \\
\text { and repair facilitias, } \\
\text { administration buildings, and } \\
\text { temporary office tacilities. }\end{array}$ & $\begin{array}{l}\text { Disassembly basin fuel, } \\
\text { target assemblies, and } \\
\text { tritiated heavy water. }\end{array}$ & $\begin{array}{l}\text { Caustic compounds, } \\
\text { acids and hydrocarbon } \\
\text { fuels }\end{array}$ \\
\hline DArea & $\begin{array}{l}\text { 400-D consists o: four operating } \\
\text { facilities: a four unit coal fired } \\
\text { powerhouse prociucing electricity } \\
\text { and } 385 \text { PSIG steam for site } \\
\text { process use, a water treatment } \\
\text { facility, a heavy water processing } \\
\text { drum storage facility which } \\
\text { processes degrauted heavy } \\
\text { water. }\end{array}$ & $\begin{array}{l}\text { Trifium (H-3), primanity } \\
\text { as an oxide and heavy } \\
\text { water. }\end{array}$ & Freon, acids, bases \\
\hline
\end{tabular}




\begin{tabular}{|c|c|c|c|}
\hline \multicolumn{4}{|c|}{ PRIMARY HAZARDS (Cont'd) } \\
\hline FDZ & DESCF!IPTION & $\begin{array}{l}\text { RADTOLOGICAL } \\
\text { HAZARDS }\end{array}$ & $\begin{array}{l}\text { CHEMICAL } \\
\text { HAZARDS }\end{array}$ \\
\hline E Area & $\begin{array}{l}\text { Concrete vaults which store low } \\
\text { level radioactive waste including: } \\
\text { the low activity waste vaults, } \\
\text { intermediate level non-tritium } \\
\text { vaults, TRU waste pads } \\
\text { intermediate tritium vaults and } \\
\text { long-lived waste storage building. }\end{array}$ & $\begin{array}{l}\text { A wide array of } \\
\text { radiological isotopes are } \\
\text { present. }\end{array}$ & $\begin{array}{l}\text { Hazards typically } \\
\text { associated with civil } \\
\text { construction activities. }\end{array}$ \\
\hline FArea & $\begin{array}{l}\text { Area process buildings supply } \\
\text { radioactive material and recover } \\
\text { radioactive material and other } \\
\text { programmatic matterials and } \\
\text { provide storage for stabilized } \\
\text { surplus nuclear materials. } \\
\text { Structures include: administration } \\
\text { buildings, warehouses, the site } \\
\text { laundry for regulated and non- } \\
\text { regulated clothing, a coal fired } \\
\text { power house, anialytical labs for } \\
\text { nuclear materiais and a high level } \\
\text { waste tank farm. }\end{array}$ & radioactive materials & $\begin{array}{l}\text { Acids, bases, nitrates, } \\
\text { hydrocarbon fueis and } \\
\text { compressed gases. }\end{array}$ \\
\hline $\begin{array}{l}\text { H-Area, } \\
\text { Tritium }\end{array}$ & $\begin{array}{l}\text { HArea Chemical Processing } \\
\text { facilities are similar to those in F } \\
\text { Area. The tritium facilities are } \\
\text { designed to extract, separate, } \\
\text { purify, and enrich specific } \\
\text { hydrogen isotopes which are then } \\
\text { packaged for shipment. Building } \\
233-H \text { is responsible for } \\
\text { processing and packaging tritium. }\end{array}$ & $\begin{array}{l}\text { Tritium, deuterium, other } \\
\text { radioactive materials }\end{array}$ & $\begin{array}{l}\text { Acids, bases, nitrates, } \\
\text { compressed gases, } \\
\text { hydrocarbon fuels and } \\
\text { laboratory reagents. }\end{array}$ \\
\hline RArea & $\begin{array}{l}\text { K Reactor facilities are utilized } \\
\text { as fuel storage facilities. } \\
\text { Additional structures include: } \\
\text { maintenance and repair facilities, } \\
\text { administration buitdings, and } \\
\text { temporary office facilities. }\end{array}$ & $\begin{array}{l}\text { Disassembly basin fuel, } \\
\text { target assemblies, } \\
\text { tritiated heavy water, } \\
\text { and unirradiated fuel in } \\
\text { the assembly areas. }\end{array}$ & $\begin{array}{l}\text { Acids, bases, } \\
\text { hydrocarbon fuels and } \\
\text { compressed gases. }\end{array}$ \\
\hline LArea & $\begin{array}{l}\text { LReactor facilities are utilized as } \\
\text { fuel storage facilities. in addition } \\
\text { to the reactor building, L-Area } \\
\text { has a variety of mlaintenance and } \\
\text { repair facilities, ardministration } \\
\text { buildings, and temporary office } \\
\text { facilities. }\end{array}$ & $\begin{array}{l}\text { Disassembly basin fuel, } \\
\text { target assemblies, } \\
\text { tritiated heavy water, in } \\
\text { the assembly areas. }\end{array}$ & $\begin{array}{l}\text { Acids, bases, } \\
\text { hydrocarbon fuels and } \\
\text { compressed gases. }\end{array}$ \\
\hline MArea & $\begin{array}{l}\text { M-Area was the ractor fuel } \\
\text { assembly fabrication area, } \\
\text { designed to produce fuel, target } \\
\text { assemblies and essential } \\
\text { materials for the site reactors. } \\
\text { Facilities include: a waste water } \\
\text { treatment area, administrative } \\
\text { buildings and various storage }\end{array}$ & $\begin{array}{l}\text { Radioactive waste, } \\
\text { uranium metals, special } \\
\text { nuclear materials }\end{array}$ & $\begin{array}{l}\text { Acids, bases, } \\
\text { hydrocarbon fuels and } \\
\text { compressed gases. }\end{array}$ \\
\hline
\end{tabular}




\begin{tabular}{|c|c|c|c|}
\hline \multicolumn{4}{|c|}{ PRIMARY HAZARDS (Cont'd) } \\
\hline FDZ & DESCRIPTION & $\begin{array}{l}\text { RADIOLOGICAL } \\
\text { HAZARDS }\end{array}$ & $\begin{array}{l}\text { CHEMICAL } \\
\text { HAZARDS }\end{array}$ \\
\hline NArea & $\begin{array}{l}\text { N-Area consists of administration } \\
\text { buildings for Bechtel Savannah } \\
\text { River Inc. (BSR), Westinghouse } \\
\text { centralized receiving } \\
\text { warehouses, maintenance and } \\
\text { equipment repar facilities, } \\
\text { construction and fabrication } \\
\text { shops. }\end{array}$ & Residual contamination. & $\begin{array}{l}\text { Battery acid, antifreeze, } \\
\text { hydrocarbon fuels, } \\
\text { various solvents, } \\
\text { compressed gases and } \\
\text { non-radioactive } \\
\text { hazardous waste. }\end{array}$ \\
\hline PArea & $\begin{array}{l}\text { PReactor faciit es are currently } \\
\text { abandoned and are scheduled to } \\
\text { undergo envirormental } \\
\text { restoration activities. }\end{array}$ & Residual contamination. & Not applicable \\
\hline RArea & $\begin{array}{l}\text { R Reactor facilities are currently } \\
\text { abandoned and are scheduled to } \\
\text { undergo environmental } \\
\text { restoration activities. }\end{array}$ & Residual contamination. & Not applicable \\
\hline SArea & $\begin{array}{l}\text { S-Area (OWPF) is the main area } \\
\text { for processing high-level } \\
\text { radioactive wastes from the } \\
\text { separations areas into } \\
\text { borosilicate glass for extended } \\
\text { storage. Additional structures } \\
\text { include: administrative, storage, } \\
\text { maintenance and support } \\
\text { facilities. }\end{array}$ & $\begin{array}{l}\text { High-level radioactive } \\
\text { waste. }\end{array}$ & $\begin{array}{l}\text { Acids, bases, } \\
\text { hydrocarbon fuels and } \\
\text { compressed gases. }\end{array}$ \\
\hline TArea & $\begin{array}{l}\text { Research and testing facilities, } \\
\text { analytical labs fcr Defense Waste } \\
\text { Pilot Testing (DVVPT), } \\
\text { administrative buildings and } \\
\text { warehouses. }\end{array}$ & Residual contamination. & $\begin{array}{l}\text { Nitric acid, uranyl nitrate } \\
\text { (aqueous and organic), } \\
\text { sulfuric acid, tributyl } \\
\text { phosphate. }\end{array}$ \\
\hline USFS Area & $\begin{array}{l}\text { This area contains United States } \\
\text { Forestry Service facilities } \\
\text { including administrative offices, } \\
\text { heavy equipment storage and } \\
\text { maintenance shops }\end{array}$ & Not applicable & $\begin{array}{l}\text { Gasoline, diesel fuel, } \\
\text { potassium nitrate, and } \\
\text { variety of herbicides and } \\
\text { pesticides. }\end{array}$ \\
\hline ZArea & $\begin{array}{l}\text { This area is responsible for the } \\
\text { processing of lowr-level } \\
\text { radioactive wastes for storage by } \\
\text { encapsulation with concrete } \\
\text { grout. }\end{array}$ & $\begin{array}{l}\text { Low-level radioactive } \\
\text { waste. }\end{array}$ & hydrocarbon fueis \\
\hline
\end{tabular}

\subsection{OTHER GENERAL, SITE HAZARDS}

In addition to preparing for Fire Department response to the highest risk FDZs, the SRS Fire Department must be prepared to respond to transportation hazardous material incidents and rescue incidents across the site. An understanding of the potential for the site's hazards beyond the FDZs further defines the operational significance of the SRS Fire Department with respect to the site hazards.

\subsubsection{Potential Transportation Hazardous Material Incidents}

The potential for transportation incidents involving hazardous materials is confirmed by the large number of shipments made across the site. Data was compiled from the Shipment Mobility/Accountability Collection System (SMAC), which summarized 
shipments of hazardous materials made by the Savannah River Site between 4/1/95 and $3 / 31 / 96$. This information is shown in Table 3.2.1.

Table 3.2.1

\begin{tabular}{|l|c|}
\hline \multicolumn{2}{|c|}{ Shipments of Hazardous Materials by DOT Hazard Class } \\
\hline \multicolumn{1}{|c|}{ Commiodity } & Total Shipments \\
\hline Explosives & 14 \\
Non-Flammable Gases & 653 \\
Compressed Gases (toxic-inhalation) & 5 \\
Flammable Gases & 126 \\
Flammable Solids & 5 \\
Oxidizers & 59 \\
Organic Peroxides & 5 \\
Poisons & 18 \\
Corrosive Materials & 256 \\
Combustible Liquids & 190 \\
Flammable Liquids & 64 \\
Non-Radiological Wiaste & 83 \\
Radiological (RAM) & 313 \\
\hline Total & 1791 \\
\hline
\end{tabular}

As shown in Table 3.2.1, there is a broad spectrum of potential hazardous material incidents on the site. Populations at risk are dependent on location and may vary in number from a very few people to thousands of people (e.g. accident near 700 area). In addition to intra-site hazardous materials shipments in support of SRS operations, consideration must be given to public shipment of hazardous materials on S.C. Highway 125 , U.S. Highway 278 , and the CSX rail line passing through SRS. The CSX rail line handles approximately six (6) one-hundred car trains per day.

The issue of emergency response to hazardous materials incidents is one that has gained significant attention in the United States during recent years. Much of this attention comes as a result of large scale releases of toxic chemicals resulting in the death or serious injury to the population near incidents. In light of such incidents, Congress passed legislation directing OSHA to develop specific labor guidelines for emergency incident responses and waste site activities. The Fire Department's hazardous materials response program is managed in accordance with OSHA 29 CFR 1910.120, NFPA Standard 472, and applicable DOE Orders. The OSHA regulations give explicit instructions concerning hazardous waste operations and emergency response.

Hazardous materials respionse capabilities are provided to the site by the SRSFD, which include offensive mitigation and defensive spill control measures. The primary response vehicle is a custom designed Hazardous Materials Unit which carries spill mitigation equipment, mobile communications, personal protective clothing, and reference material. The department provides mutual aid to surrounding Aiken, Allendale and Barnwell counties in South Carolina as well as Augusta-Richmond county in Georgia. The department also provides assistance to other counties upon request.

\subsubsection{Potential Rescue Incidents}

The need for rescue capability is unpredictable. Natural hazard events, such as tomadoes and earthquakes are possible for the SRS, and these events are likely to 
require rescue capabilities. One possible worst case scenario involves a natural disaster such as an earthquake or a tornado which impacts a highly populated, multistoried facility such as 703-A or 730-B. With the recent construction of several of these type facilities in the same locale, the potential for impact increases proportionately with a large life safety hazard potential.

In addition to natural disasters, SRS has the need for rescue capability in response to operating mishaps. Numerous jobs on site require entry into confined space creating an inherent need for confined space rescue capability. In addition, construction, decommissioning, and demolition activities create the need for rescue capability.

\subsection{HAZARD CLASSIFICATION BY FDZ}

Each facility within a FDZ has the potential need for some level of emergency response. This need varies based on the risk associated with the facility, which include life safety concerns, facility hazards, and importance of the facility to site missions. By basing Fire Department response planning on facility fire risk, the Fire Department is best positioned to manage an emergency event under it's control.

The fire demand zones were evaluated and assigned response levels. Refer to Table 4.0. .Numeric response levels were developed and assigned values from 1 to 4 , with response level 1 assigned to FDZs with the greatest fire risk thus requiring the most prompt and greatest availability of fire department response resources. Risk associated attributes were assigned to each response level. Response level assignments were based on possession of at least one resijonse level attribute by at least one facility within the FDZ. The highest response level found for a facility within a FDZ was then assigned to the entire FDZ.

Table 4.0

\begin{tabular}{|c|c|c|}
\hline \multicolumn{3}{|c|}{ FDis Response Level Assignments } \\
\hline $\begin{array}{c}\text { Response } \\
\text { Level }\end{array}$ & Description of Fire Demand Zone & $\begin{array}{l}\text { Fire Demand Zone } \\
\text { Corresponding to Each } \\
\text { Response Level }\end{array}$ \\
\hline$T$ (High) & $\begin{array}{l}\text { - Nuclear Safeti } \\
\text { - Potential Public Endangerment } \\
\text { - Vital DOE Program } \\
\text { - Dollar loss }>25 \text { million } \\
\text { - FD Considered Redundant Suppression }\end{array}$ & F, H, S, A \\
\hline 2 & $\begin{array}{l}\text { - mportant DOE: Program } \\
\text { - Dollar loss frorn } 5 \text { to } 25 \text { million } \\
\text { - Critical Production Support }\end{array}$ & $B, N, D, L, K$ \\
\hline 3 & $\begin{array}{l}\text { - Dollar loss between } 1 \text { and } 5 \text { million } \\
\text { - General Support Facilities } \\
\text { - Administration Facilities }\end{array}$ & C, E, M, Z \\
\hline 4 (Low) & $\begin{array}{l}\text { - Dollar loss < } 1 \text { million } \\
\text { - Non-impacting facility }\end{array}$ & $\begin{array}{l}\text { R,P, T, USFS, Isolated } \\
\text { Facilities on-site }\end{array}$ \\
\hline
\end{tabular}

\subsection{FIRE DEPARTMENT REQUIREMENTS}

Fire station locations, equipment and availability of trained personnel must satisfy the planning basis in order for the SRS Fire Department (SRSFD) to fulfill its mission. The 
mission of the SRSFD is defined by the services that SRS requires of its Fire Department.

The services provided are pre-planning activities, training, emergency response work control, procedures development, fire suppression, emergency medical, hazardous material and technical rescue response. The department also provides maintenance functions for approximately 7,300 fire extinguishers and an additional 500 fire protection components and 389 buildirg observations on a periodic basis across the site. Sections 5.1 - 5.7 detail the SRSFD emergency response services expected by SRS.

Availability of trained eme:gency personnel is the most crucial factor influencing the SRSFD's ability to carry out the delivery of the emergency services for the Site. Personnel requirements are measured through several means including the emergency response missions of the department and the extent to which these services will be provided. The extent to which each service is provided has been determined through site hazards analysis. The number of personnel required to provide effective response to emergency incidents is baser on applicable regulatory requirements where they exist and accepted practices for emergency response.

Adequate personnel availability is determined by establishing baseline emergency incidents for the emergency response missions of the SRSFD and demonstrating through task analysis the number of responders needed to resolve the incidents. A description of the baseline emergency incidents for the site are listed in Table 5.0.

Table 5.0

\begin{tabular}{|c|l|}
\hline \multicolumn{2}{|c|}{ Baseline Emergency lncidents for SRSFD } \\
\hline Incident Type & \multicolumn{1}{|c|}{ Incident Description } \\
\hline Fire Suppression & $\begin{array}{l}\text { Afire requiring interior fire attack and a } \\
\text { sustained firefiow via two hand-held } \\
\text { attack lines totaling 400-500 gpm. }\end{array}$ \\
\hline Emergency Medical & $\begin{array}{l}\text { Provision of one Advanced Life } \\
\text { Support (ALS) ambulance with } 2 \\
\text { person team dedicated to EMS at any } \\
\text { baseline incident (fire suppression, } \\
\text { haz-mat, or technical rescue) and one } \\
\text { additional ALS ambulance with a 2 } \\
\text { person team available to respond to a } \\
\text { second independent EMS incident. }\end{array}$ \\
\hline Hazardousi Materials & $\begin{array}{l}\text { Transportation or fixed facility incident } \\
\text { requiring Level A entry operations. }\end{array}$ \\
\hline Technicar Rescue & $\begin{array}{l}\text { Any one of the following incidents: } \\
\text { confined space, high angle rope, } \\
\text { trench or structural collapse, or vehicle } \\
\text { extrication. }\end{array}$ \\
\hline
\end{tabular}

The baseline incidents described in Table 5.0 represent the incidents which will be used to determine emergency response shift stafing requirements. The following "bounding conditions" apply to all baseline emergency incidents analyzed.

- Implement Authorization Basis fire suppression requirements (Safety Analysis Report /Basis for Interim Operation/Justification for Continued Operation)

- Fire development limited to $10 \%$ of the potential fire area or a two-room fire with a high confidence level. 
- Baseline response is a single incident with a single casualty. If a casualty does not actually exist at the incident and the $2^{\text {nd }}$ EMS response is requested elsewhere on-site, the EMS ambulance on the fire scene will be available to respond appropriately.

- Comply with medical control physician's guideline of 2 EMS units, committed to EMS duties only.

- Fire flow capability is two hose lines capable of delivering a total of 400 $500 \mathrm{gpm}$.

- Staffing levels are established for the purpose of life safety and protection of the public.

\subsection{Fire Suppression Iocident Staffing Analysis}

\subsubsection{Background}

The SRSFD provides fire suppression capabilities for the site by state-certified firefighters trained to the Firefighter Level II established by NFPA 1001. The department responds to all types of fires ranging from interior structural fires to grass fires and has a call volume of approximately 1000 alarms per year of which approximately $4 \%$ are actual .fires. The department is governed by NFPA Standards and Codes as the regulatory documents for departmental operation and response. The SRSFD currently has a joint mutual aid agreement with Aiken, Allendale and Barnwell Counties, South Carolina and Augusta-Richmond County, Georgia. These mutual aid agreements provide ambulances, non-nuclear structural firefighting and hazardous materials support. The SRSFD also provides aid to surrounding communities as requested.

The following factors are appropriate for evaluating site fire suppression capability regardless of whether it is made up of a fire brigade, a site fire department, an off-site fire department, or some combination of the three. DOE Order 6430.1A, Section 1530-2.3.5 states:

"...The fire department capability to reduce loss due to a well developed fire shall be considered in terms of the following factors:

- Location of fire station(s) with respect to the facility to be protected

- Staffing of stations (e.g., continuously or "on-call")

- Ability to perform initial fire attack as outlined in NFPA 1410

- Method(s) of fire department notification or alarm reception

- Familiarity of starion staff with the DOE facility, and training in preparation for effective response to an alarm at the DOE facility

- Degree of commitment that a fire department(s) makes to respond to fire emergencies in DOE facilities. This factor shall be emphasized."

Two of the listed factors affect response time to the scene: location of fire stations and method(s) of fire department notification. Two of the factors affect personnel and 
equipment needs: availability of personnel and ability to perform initial fire attack as outlined in NFPA 1410.

NFPA 1410 is the training standard on initial fire attack. There are several timed handline evolutions in the standard which are used to improve the ability of a fire department to deliver water on an initial attack. Section A-4-1.1 hose evolution no. 1, representing an interior structural fire suppression effort requiring a fire flow of $300 \mathrm{gpm}$, is a typical initial attack scenario. This evolution, modified to provide a flow of $400-500 \mathrm{gpm}$, is the standard used for training by the SRSFD. This evolution when applied to normal fireground operations requires nine personnel as follows: two attack lines with two personnel each, one rapid intervention crew consisting of two personnel, one pump operator, one Safety Officer, and one Incident Commander.

NFPA 1201, "Developing Fire Protection Services for the Public" defines the basic response unit in a fire department as a "fire company". NFPA 1500 , Section 6-4.1, states, "The fire department shall provide an adequate number of personnel to safely conduct emergency scene operations. Operations shall be limited to those that can be safely performed by the personnel available at the scene." The appendix to Section $6-4.1$, states "It is recommended that a minimum acceptable fire company staffing level consist of four members responding on or arriving with each engine or aerial ladder company responding to any type of fire." SRS defines that basic response unit as a station. Each station has a minimum of 5 personnel and at least one engine and one ambulance. Some stations also have special purpose apparatus such as ladder, rescue, and hazardous material response vehicles. Therefore, in order to successfully implement the SRS modification of NFPA 1410, Section A-4-1.1, no. 1, two stations must respond of which one must respond an engine.

While the SRS-modified NFPA 1410 interior structural fire suppression evolution requires two stations, of which at least one must respond an engine, on a real fire similar to that postulated in NFPA 1410 , there is a need for additional resources to handle other activities which are equally important to effective and safe fire ground operations. These activities include search and rescue, ventilation, control of utilities, protection of exposures, emergency medical service, firefighter relief and rehabilitation, salvage, and overhaul. Each of these tasks requires a team consisting of at least two firefighters. Use of these additional teams maly necessitate response of additional personnel to a real fire. The number of additional personnel needed varies with the tasks called for by the real emergency situation.

To arrive at reasonable personnel levels several realistic and credible potential SRS fire scenarios (as documented in facility fire hazards analyses) were analyzed and anticipated fireground staffing levels determined. The assumptions used to develop these credible fire scenarios include bounding conditions/limitations from the DOE Implementation Guide for the 420.1 and 440.1 Orders. The assumption of an emergency response to a single incident with a single casualty is the baseline. Additional assumptions included a limitation on the fire development to $10 \%$ of the potential fire area. Where this limitation in fire development cannot be justified based upon excessive response times due to delayed alarm notification, larger travel times, etc. and the lack of fixed fire protection, 
then the credible fire scenario development in excess of $10 \%$ involvement should be used. Such fire scenario development in excess of the (10\%) baseline assumption limitation should be substantiated by consensus agreement between WSRC (a line manager, a Fire Protection Engineer (FPE), and the Fire Chief) and the DOE-SR FPE.

\subsubsection{Staffing Analysis}

The response to two types of events is provided in this section. A baseline response level, which includes personnel that must be on-site and must be available to respond to the primary incident, is justified based on the ability of the SRSFD to provide adequate response to $99 \%$ of all preplanned structures. For the small number of higher hazard facilities, special staffing needs are identified and possible methods of meeting those needs are proposed. For all alarms there is the possibility that Fire Department response may be negatively impacted due to commitment of resources to prior incidents (availability) or unanticipated events preventing successful arrival and mitigation of the incident (reliability). These issues are addressed in the following engineering calculations:

- "Fire Department Availability", F-CLC-G-00016

- "Fire Severity Probability Based on Fire Timeline", F-CLC-G-00015

- "Authorization Basis Fire Department Functional Requirements", S-CLC-G00151

\subsubsection{Baseline Staffing}

Of the 396 preplanned structures at SRS, 393 or $99 \%$ can be managed, within the "bounding conditions", with the following shift staffing:

Table 5.1.2.1

\begin{tabular}{|l|c|}
\hline \multicolumn{2}{|c|}{ Task Analysis Minimum Staffing Summary } \\
\hline Task Required & $\begin{array}{c}\text { Personnel Required To } \\
\text { Mitigate Incident }\end{array}$ \\
\hline $\begin{array}{l}\text { Charge and Advance Attack } \\
\text { Lines }\end{array}$ & 4 \\
\hline Rapid Intervention Crew & 2 \\
\hline Search and Res.cue & 4 \\
\hline Apparatus Operator & 2 \\
\hline Safety Officer & 1 \\
\hline Incident Commander & 1 \\
\hline EMS at Incident Scene & 2 \\
\hline TotalPersonnel: & 16 \\
\hline
\end{tabular}

Example scenarios in this category include:

\section{HB-Line:}

A fire in the HB-Line hard structure was analyzed to verify that the Authorization Basis $(A B)$ document safety envelope is not violated. The $A B$ Document assumes this fire can start anywhere in the HB-Line hard structure. The scenario analyzed assumes that there is one casualty. Engineering calculation S-CLC-G-00151 "Authorization Basis Fire Department Functional Requirements" has determined the current draft $A B$ Document safety envelope is preserved if the SRSFD successfully performs the following at least $50 \%$ of the time: 1 ) is capable of flowing water onto the fire at about $400 \mathrm{gpm}$ or greater within approximately 20 
minutes of receipt of the alarm at the Operations Center (911 Center) and 2) extinguishes the fire within approximately 20 minutes of initiating fire attack. Mitigating this scenario was found to require a total of 16 on-scene personnel: one incident commander, one safety officer, two apparatus operators (either 2 pump operators or one pump operator and one truck apparatus operator), one Rapid Intervention Ciew (two firefighters), two attack teams (four fire fighters), two search and rescue teams (four fire fighters), and one EMS team (two fire fighters). The critical functions of forcible entry, search and rescue, and suppression which are necessary to promote life safety and preserve the $A B$ Document safety envelope must be initiated within approximately 20 minutes of receipt of the alarm in the SRSOC. The first two arriving stations, the Safety Officer, and the Battalion Chief, totaling at least 12 personnel can initiate the critical functions while the third station is enroute to the scene.

\section{Building 233-H:}

A fire in $233-\mathrm{H}$ was analyzed to verify that the $A B$ document safety envelope is not violated. The AES Document assumes this fire can start anywhere in 233-H. The scenario analyzed assumes that there is one casualty. Engineering calculation S-CLC-G-00151 has determined the current draft AB Document safety envelope is preserved if the SRSFD successfully performs the following at least $20 \%$ of the time: 1) is capable of flowing water on the fire at about 400 gpm or greater within approximately 20 minutes of receipt of the alarm at Operations Center ( 9.11 Center) and 2) extinguishes the fire prior to extension through a fire barrier into another fire zone. This scenario was found to require a total of 16 on-scene personnel: one incident commander, one safety officer, two apparatus operators (either 2 pump operators or one pump operator and one truck apparatus operator), one rapid intervention team (two firefighters), two attack teams (four fire fighters), two search and rescue teams (four fire fighters), and one EMS team (two fire fighters). The critical functions of forcible entry, search and rescue, and suppression which are necessary to promote life safety and preserve the $\mathrm{AB}$ Document safety envelope must be initiated within approximately 20 minutes of receipt of the alarm in the SRSOC. The first two arriving stations, the Safety Officer, and the Battalion Chief, totaling at least 12 personnel can initiate the critical functions while the third station is enroute to the scene.

\section{Receiving Basin for Offsite Fuels (RBOF):}

A fire in the RBOF was analyzed. The scenario analyzed assumes that there is one casualty. This scenario was found to require a total of 16 on-scene personnel: one incident commander, one safety officer, two apparatus operators (either 2 pump operators or one pump operator and one truck apparatus operator), one rapid intervention team (two firefighters), two attack teams (four fire fighters), two search and rescue teams (four fire fighters), and one EMS team (two fire fighters).

\section{6-H \& B Area Office Complex (730-B, 730-1B, 730-2B \& 730-4B)}

Due to the high level of fixed fire suppression in $766-\mathrm{H}$ and the B Area Complex, the fire risk posed is greatly reduced. The scenario analyzed again assumes that there is one casualty. This scenario was found to require a total of 16 on-scene personnel: one incident commander, one safety officer, two apparatus operators (either 2 pump operators or one pump operator and one truck apparatus operator), one rapid intervention team (two firefighters), two attack teams (four fire fighters), two search and rescue teams (four fire fighters), and one EMS team (two fire fighters). 


\subsubsection{Facility Fires Which Exceed Baseline Staffing}

Two of the three facilities which take explicit credit for a FD response in the $A B$ document are included in the above description (HB-Line and 233- $\mathrm{H}$ ) and meet baseline staffing requirements.

\section{SRTC}

However, SRTC emergency response requirements for the $A B$ Document based fire exceed the staffing levels for the baseline. A fire in the SRTC was analyzed to verify that the $A B$ document safety envelope is not violated. The $A B$ Document assumes this fire can start anywhere in the SRTC. The scenario analyzed assumes that there is one casualty. Engineering calculation S-CLC-G00151 "Authorization Basis Fire Department Functional Requirements" has determined the current draft $A B$ Document safety envelope is preserved if the SRSFD performs the following at least $50 \%$ of the time: 1) is capable of flowing water onto the fire up to about $400 \mathrm{gpm}$ within approximately 20 minutes of receipt of the alarm at the Operations Center (911 Center) for a two room fire or is capable of flowing water onto the fire at $1000 \mathrm{gpm}$ or greater within approximately 20 minutes of receipt of the alarm at the Operations Center (911 Center) if the fire is greater than 2 room involvement and 2) extinguishes the fire prior to extension through a fire barrier into another fire zone. The SRTC fire can be managed with the following staffing:

Table 5.1.2.2A
\begin{tabular}{|l|c|}
\hline \multicolumn{1}{|c|}{ SRTC Task Analysis Minimum Staffing Summary } \\
\hline \multicolumn{1}{|c|}{ Task Required } & $\begin{array}{c}\text { Personnel Required To } \\
\text { Mitigate Incident }\end{array}$ \\
\hline $\begin{array}{l}\text { Charge and Aclvance Attack } \\
\text { Lines }\end{array}$ & 4 \\
\hline Rapid Intervention Crew & 2 \\
\hline Search and Reiscue & 4 \\
\hline Apparatus Operator & 2 \\
\hline Safety Officer & 1 \\
\hline Incident Commiander & 1 \\
\hline EMS at Incident Scene & 2 \\
\hline Multifunction Team* & 2 \\
\hline TotalPersonniel: & 18 \\
\hline Multifunction team may be staffed by the 2nd SRS ALS Ambulance.
\end{tabular}

The difference between the baseline staffing level and SRTC is two responders which will perform tasks as the multifunction team. Examples of multifunction team duties include: master stream application, exposure control, and ventilation. The response time for these functions is critical, but not as much so as search \& rescue, initial attack and sprinkler augmentation. The most reasonable method to provide the additional needed personnel for the multifunction team is the second SRS EMS ambulance which could be committed to these tasks. If the second SRS EMS ambulance is committed to non-EMS incident operations, mutual aid must be immediately activated to provide the 2nd ALS ambulance required for the 2 nd potential EMS incident. There is a certain amount of risk assumed with this approach, based on an approximate mutual aid response time of 50 minutes, in being able to respond to a 2nd simultaneous EMS incident. The critical functions of forcible entry, search and rescue, and suppression which are necessary to promote life safety and preserve the $A B$ Document safety envelop must be initiated within approximately 20 minutes of receipt of the alarm in the SRSOC. The first two 
arriving stations, the Safety Officer, and the Battalion Chief, totaling at least 12 personnel can initiate the critical functions while the third station is enroute to the scene.

If the second floor of A-Wing and the non-protected areas of D-Wing (with the exception of the Fabrication Laboratory) are provided with automatic sprinklers, then the fire development and smoke propagation will be mitigated for this fire scenario to the extent that a staffing reduction of 2 personnel can be accomplished.

Two other SRS facilities exceed the baseline staffing. These facilities include 221-F Canyon and 703-A. The fire scenarios at each of these facilities are significantly different with $221-F$ being a substantial outlier. Each of these two scenarios is described.

\section{1-F Canyon}

$221-\mathrm{F}$ is a large, relatively unprotected (in terms of fixed fire protection) nuclear facility which has several scenarios that could require high FD response staffing. These scenarios are more severe because of a lack of detection systems, inadequate fixed suppression systems, and a tremendous potential of fire propagation among the various levels of the structure. This combination results in a potentially larger fire, involving a greater percentage of the building than other nuclear facilities. The proper staffing and one such scenario is described below:

Fire in the 221-F Canyon, a situation not described by a $A B$ Document, was postulated as originating in a cable tray on the 2 nd level and that there is one casualty. For this scenario a fire is assumed on one level with the 400 gpm attack also confined to that level. This scenario was found to require a total of 18 onscene personnel: one incident commander, one safety officer, two apparatus operators (either 2 pump operators or one pump operator and one elevating ladder operator), one rapid intervention team (two firefighters), two attack teams (four fire fighters - 2 attack lines on 2 nd level), three search and rescue teams (six fire fighters - 2 per floor), one EMS team (two fire fighters). Hose is being prepositioned in the stairwell to reduce set-up time.

Table 5.1.2.2.B

\begin{tabular}{|l|c|}
\hline \multicolumn{2}{|c|}{$\begin{array}{c}\text { 221-F (CANYON) Task Analysis Minimum Staffing } \\
\text { Summary }\end{array}$} \\
\hline \multicolumn{1}{|c|}{ Task Required } & $\begin{array}{c}\text { Personnel Required To } \\
\text { Perform Task }\end{array}$ \\
\hline $\begin{array}{l}\text { Charge and Advance Affack } \\
\text { Lines }\end{array}$ & 4 \\
\hline Rapidintervention Crew & 2 \\
\hline Search and Rescue & 6 \\
\hline Apparatus Operator & 2 \\
\hline Safety Officer & 1 \\
\hline Incident Commander & 1 \\
\hline EMS at Incident Scene & 2 \\
\hline TotalPersonnel: & 18 \\
\hline
\end{tabular}

A safety line is provided through the RIC in case the search and rescue team on the floor above the fire is threatened. This involves some risk but is within acceptable practice. The fire is assumed to be very smoky and the three search and rescue teams are believed to be critical to quick victim rescue. 
The 18 staffing proposal for this scenario follows that for SRTC (i.e., the second SRS -ambulance may be committed to non-EMS incident operations and mutual aid requested for the 2 nd uncommitted ambulance.)

If the cable tray fire hazard is protected by automatic sprinklers, then the fire development and smoke propagation will be mitigated for this fire scenario to the extent that a staffing reduction of 2 personnel can be accomplished.

703-A

This building is a rnulti-story office building which could involve significant search and rescue or other building tactics. Special hazards were noted in the following locations:

- $\quad$ A Wing - Diesel tank

- C Wing - Diesel tank

- D Wing - Cornputer Room

However, all of these hazard areas are protected by a sprinkler and detection system which provides reasonable assurance of timely notification of alarm and suppression system activation. The staffing for the response to this building is:

Table 5.1.2.2.C

\begin{tabular}{|l|c|}
\hline \multicolumn{2}{|c|}{ 703-A Task Analysis Minimum Staffing Summary } \\
\hline Task Required & $\begin{array}{c}\text { Personnel Required To } \\
\text { Perform Task }\end{array}$ \\
\hline $\begin{array}{l}\text { Charge and Advance Attack } \\
\text { Lines }\end{array}$ & 4 \\
\hline Rapidintervention Crew & 2 \\
\hline Search and Rescue & 4 \\
\hline Apparatus Operator & 2 \\
\hline Satety Officer & 1 \\
\hline Incident Commander & 1 \\
\hline EMS at Incideni Scene & 2 \\
\hline Multifunction Team & 2 \\
\hline TotalPersonnel: & 18 \\
\hline
\end{tabular}

Again, the most reasonable method to provide the additional needed personnel for the multifunction team is the second SRS EMS ambulance which could be committed to these tasks. If the second SRS EMS ambulance is committed to non-EMS incident operations, mutual aid must be immediately activated to provide the 2nd ALS ambulance required for another potential EMS incident.

If effective administrative accountability is provided 24 hours a day, 7 days a week in 703-A, ther the shift staffing for this scenario can be reduced by 2 personnel. In order to accomplish effective accountability, the following will need to be done:

(1) facility fire wardens must perform inspection sweeps of non-involved building wings for accountability. Effective accountability must be established at or before the point where the Fire Department is ready to enter the facility to perform interior attack and search and rescue. 
(2) WSI should maintain an accountability log for off-shift hours at the WSI checkpoint in 703-46A. The accountability log should be structured to accommodate the around-the-clock operations of the EOC and the Computer Facility. The rally point for off-shift hours will be at 703-46A. Furthermore, all facility personnel working beyond 6:00 P.M. must log-in at 703-46A.

The eleven (11) scenarios above represent the worst-case fire scenarios for SRS within the established "bounding conditions".

Referring again to $6430.1 \mathrm{~A}$, Section $1530-2.3 .5$, fire department capability factors include resource needs (personnel and equipment) and response time capability. Having defined anticipated staffing levels and identified available equipment resources, response time capabilities will now be established. The factors related to response time (from Section 1530-2.3.5) are fire station location and method of fire department notification or alarm reception.

Due to ancillary duties (i.e. preplan walkdowns, fire extinguisher servicing, etc.) personnel on duty at the SRSi fire stations may be at locations remote from the fire station or the apparatus but provicled with a vehicle with which to respond directly to the emergency. It is important to understand that response times assume that all station personnel arrive as a unit and that fire fighters who cannot arrive at the fire scene within the critical response time period can not be considered part of the initial attack assignment.

The National Fire Protection Association Fire Protection Handbook (18th edition), section 10, chapter 20, "Planning Fire Station Locations", defines Fire Department response time as follows:

Initiation time: Time from ignition to discovery and reporting time. This time period is not completely manageable due to time delays associated with initiating and alarm transmitting devices such as surge chambers, autoterms, and central station computer. It is also not managed by the Fire Department, has a high degree of variability depending on the presence of fixed fire protection, and is therefore not included in the time calculations which follow.

Dispatch time: Amount of time that it takes to receive and process an emergency call or alarm. This ircludes: (1) receiving the call or alarm, (2) determining what the emergency is, (3) verifying where the emergency is located, (4) determining what resources are required to handle the call or alarm, and (5) notifying the units that are to respond.

Tura-out time: Amount of time that it takes a crew to: (1) react after receiving dispatch information and (2) prepare to leave the station.

Travel time: Amount of time that it takes for a piece of apparatus to travel from the fire station to the incident scene. (The amount of time from wheel start to wheel stop.)

Access time: Amount of time required for the crew to move from where the apparatus stops to where the emergency exists. This can include moving to the interior or upper stories of a large building and dealing with any barriers in the access to that area. 
Set-up time: The amount of time required for fire department units to set up, connect hose lines, position ladders, etc., and prepare to extinguish the fire.

Dispatch time starts when the alarm enunciates at the Operations Center (911 Center) or the telephone call is received at the Operations Center $(911$ Center). Dispatch time includes that time necessary to select the appropriate apparatus and personnel and notify them to respond. At SRS dispatch time is an estimated maximum of one minute.

Turnout activities may occur at the fire station or at the fireground since some SRSFD personnel respond from locations other than the fire station. Regardless of where these activities occur tumout time is that time necessary for the dispatched apparatus and personnel to prepare to perform their fireground functions (e.g. donning personal protective equipment). SRSFD personnel turnout time is an estimated maximum of 2 minutes.

Travel time is the actual vehicular travel time from location at the time of dispatch to arrival at the fire scene. Assigning appropriate travel times for fire apparatus to arrive at specific facilities has been aitempted both quantitatively and qualitatively for years. Run time studies, theoretical calculations and calculations based on rules of thumb are common. The Insurance Service Office (ISO) allows mobile water supply travel times to be calculated by multiplying a rule of thumb value $(35 \mathrm{mph}$ ) by the travel distance. ISO established $35 \mathrm{mph}$ as a reasonable average speed after analysis of many rural mobile water supply operations conclucted throughout the United Stares. Over the years SRS has analyzed fire department travel times via run time studies, theoretical computations, and calculations using other rules of thumb. Comprehensive analysis was performed in 1989 and 1992 by Professional Loss Control (PLC). In 1989 PLC used a rule of thumb calculation employing 44 miles per hour as the travel constant. In 1992 PLC ran motion studies which were used to develop run time maps. In 1996 and 1997 WSRC conducted run time studies and performed theoretical computations to establish estimated travel times. It is important to note that site conditions changed significantly between each of the previous studies. Upon analysis of the previous studies and assessment of ISO's rule of thumb calculation methodology the needs analysis team determined that the most realistic overall method was to use a rule of thumb calculation. The team established an average response speed of $40 \mathrm{mph}$ ( 1.5 minutes per mile travel time) since SRS is a rural setting with wide, modern, relatively-flat, unobstructed roads. Response of firefighters from locations other than fire stations was not analyzed separately since site experience indicates these firefighters tend to arrive at the incident scene at approximately the same time as the fire apparatus dispatched from the fire stations. SRS travel distances were obtained from Engineering Calculation FCLC-G-00014, "Fire Department Response Time Analysis, Generic Estirnate".

Access time includes such activities as instituting appropriate radiation controls, locating the proper access to the fire: area, obtaining and evaluating accountability information from facility personnel. Access time is estimated to require no more than 2 minutes.

Set-up time allows for setting up two $200-250 \mathrm{gpm}$ attack lines and initiating the critical functions of forcible entry ard search and rescue. Set-up time is estimated to require no more than 4-1/2 minutes for most facilities.

Response time for SRS is the arithmetic sum of the following:

Dispatch time: 1 minute (maximum value)

Turn-out time: $\quad 2$ minutes (maximum value) 
Travel time:

Calculated by the needs analysis team or from run time study

Access time: $\quad 2$ minutes (maximum value)

Set-up time: $\quad 4.5$ minutes (maximum value)

Upon completion of the rule of thumb calculations the team compared the results with those reported in Engineering Calculation FCLC-G-00014, "Fire Department Response Time Analysis, Generic Estimate". With the exception of responses by Station 1 involving travel on E Road from $C$ Road to Road 4 all calculated response times were either conservative or comparable (within 15 seconds of the values reported in the engineering calculation). The team's calculated values for Station 1 responses involving travel on road $\mathrm{E}$ from Road $\mathrm{C}$ to Road 4 were nonconservative (maximum deviation of 1.4 minutes from Station 1 to $\mathrm{Z}$ Area). The team recommends a run time study be initiated over an extended period of time for all categories of fire department responses.

Response time thus reduces to the sum of the travel time plus 9.5 minutes. The response time values are presented in Table 5.1B which follows. It should be noted that the response time includes two minutes access time and 4.5 minutes setup time for each of the station response times. This is appropriate for the maximum time estimates but may be overly conservative from some functions performed by the 2 nd and 3 rd station responses.

Table 5.1B

\begin{tabular}{|c|c|c|c|c|c|}
\hline \multicolumn{6}{|c|}{$\begin{array}{l}\text { Structure Fire Response Maximum Time Estimates } \\
\text { (Time from receipt of alarm in Operations Center (911 Center) until capable of flowing } \\
\text { water at incident scene.) }\end{array}$} \\
\hline $\begin{array}{c}\text { Response } \\
\text { Level }\end{array}$ & $\begin{array}{c}\text { Risk/Hazard } \\
\text { Level }\end{array}$ & $\begin{array}{c}\text { Fire Demand } \\
\text { Zone } \\
\text { Corresponding to } \\
\text { Each Response } \\
\text { Level }\end{array}$ & $\begin{array}{l}\text { Tst Station } \\
\text { Response } \\
\text { Time in } \\
\text { Minutes } \\
\text { (Station } \\
\text { Respond- } \\
\text { ing) }\end{array}$ & $\begin{array}{l}\text { 2nd Station } \\
\text { Response } \\
\text { Time in } \\
\text { Minutes } \\
\text { (Station } \\
\text { Respond- } \\
\text { ing) }\end{array}$ & $\begin{array}{l}\text { 3rd Station } \\
\text { Response } \\
\text { Time in } \\
\text { Minutes } \\
\text { (Station } \\
\text { Respond- } \\
\text { ing) }\end{array}$ \\
\hline$T$ & Maximum & $\begin{array}{c}F \\
H^{*} \\
\text { ITP } \\
\text { Tritium } \\
S \\
A^{*}\end{array}$ & $\begin{array}{c}9.65(1) \\
13.85(1) \\
13.85(1) \\
13.85(1) \\
15.2(1) \\
10.40(2)\end{array}$ & $\begin{array}{l}18.65(3) \\
18.50(3) \\
18.50(3) \\
18.50(3) \\
19.85(3) \\
19.85(1)\end{array}$ & $\begin{array}{l}19.55(2) \\
22.40(2) \\
22.40(2) \\
22.40(2) \\
23.75(2) \\
27.50(3)\end{array}$ \\
\hline 2 & High & $\begin{array}{l}B \\
N \\
D \\
L \\
K\end{array}$ & $\begin{array}{l}15.95(2) \\
14.3(3) \\
24.20(3) \\
11.45(3) \\
14.60(3)\end{array}$ & $\begin{array}{l}16.40(1) \\
14.9(1) \\
24.8(1) \\
20.60(1) \\
19.4(1)\end{array}$ & $\begin{array}{l}24.05(3) \\
23.45(2) \\
25.10(2) \\
29.15(2) \\
27.95(2)\end{array}$ \\
\hline 3 & Ordinary & $\begin{array}{l}\text { C } \\
\text { M } \\
Z\end{array}$ & $\begin{array}{l}16.10(1) \\
12.2(1) \\
10.70(2) \\
15.20(1)\end{array}$ & $\begin{array}{l}17.75(3) \\
18.65(3) \\
20.15(1) \\
19.85(3)\end{array}$ & $\begin{array}{l}24.65(2) \\
20.75(2) \\
27.80(3) \\
23.75(2)\end{array}$ \\
\hline 4 & Low & $\begin{array}{l}R \\
P \\
\text { TNX } \\
\text { USFS }\end{array}$ & $\begin{array}{l}15.95(3) \\
13.7(3) \\
24.95(3) \\
20.90(2)\end{array}$ & $\begin{array}{l}21.95(1) \\
22.55(1) \\
25.55(1) \\
22.25(1)\end{array}$ & $\begin{array}{l}30.50(2) \\
31.10(2) \\
25.85(2) \\
29.90(3)\end{array}$ \\
\hline
\end{tabular}

FDZs are locations of Authorization Basis $(A B)$ Document fire scenarios. 
Facility protection such as automatic sprinklers, automatic detection, continuous occupancy, etc., may allow an increase in the minimum response time for Fire Department personnel and may impact resource assignments. Responding to a well protected facility, as a rule of thumb, may involve less strenuous fire ground operations.

Of particular importance is the department's capability to mitigate $A B$ Document based fires. As indicated previousily, $A B$ Document based fires require a minimum of $16-18$ personnel at the scene for complete mitigation, which requires dispatch of three stations, the Battalion Chief, and the Safety Officer. All AB Document fires require the capability to initiate forcible entry, search and rescue, and suppression operations within approximately 20 minutes of receipt of the alarm at the Operations Center (911 Center). The critical functions of forcible entry, search and rescue, and suppression which are necessary to promote life safety and preserve the AB Document safety envelope must be initiated within approximately 20 minutes of receipt of the alarm in the SRSOC. The first two arriving stations, the Safety Officer, and the Battalion Chief, totaling at least 12 personnel can initiate the critical functions while the third station is enroute to the scene.

In summary, fire alarm calls are the most frequently requested emergency response service at the SRS. These alarms vary from false alarms to full suppression incidents. There are currently about four hundred buildings on the site with preplans which would require interior fire attack capabilities in the event of fire. In order to meet the response times established for site facilities, personnel must be distributed strategically across the.site. -The staffing identified in this analysis is that required on the emergency scene. Therefore, total minimum staffing will require additional personnel to allow for such items as vacation, disability, training, etc.

\subsection{Emergency Medical Service Staffing Analysis}

The delivery of prompt medical care for intervention in potentially life-threatening emergencies to the entire site: population requires that sufficient personnel and equipment be available on a continuous basis. Emergency medical service needs at SRS have been analyzed based on the site's demand for service delivery and applicable regulatory requirements of the South Carolina Department of Health and Environmental Control (SCDHEC).

SRSFD provides Advanced Life Support (ALS) emergency medical service licensed by SCDHEC. An ambulance is assigned to each fire station and responds to the same site areas as the co-located fire apparatus. ALS coverage is provided continuously on a 24hour basis by Stations 1 and 2. Station 3 provides ALS coverage at least $90 \%$ of the time and BLS coverage the remainder of the time. Each ambulance is staffed by two personnel whose minimum qualifications for ALS response are one Paramedic and one basic Emergency Medical Technician (EMT). When operating as a BLS unit both responders are at least basic EMTs. The emergency medical service responds to approximately 400 calls per year distributed as follows:

$$
\begin{array}{lr}
\text { Medic 1, Station 1 } & 60 \% \\
\text { Medic 2, Station 2 } & 38 \% \\
\text { Medic 3, Station 3 } & 2 \%
\end{array}
$$

Of the 400 calls, approximately 100 are off-site transports which involves a commitment time of approximately 2 hours. There are also about 100 calls which require transport to an on-site medical facility which takes about 1 hour to complete. 
Site hazard analysis has determined that the SRS has an average daytime population of 12,000 and an off-shift population of 2,000. SCDHEC guidance recommends one inservice ambulance for each population group of 5,000 persons. The sheer size of SRS, geographic separation of high population density industrial and administrative areas, and the presence of significant quantities of hazardous and radiological materials increases the number of needed ambulances as well as influences their distribution. Therefore, SRSFD normally maintains 3 ALS ambulances in service during day shift and at least 2 ALS ambulances in service on off-shifts.

Normal EMS dispatch protocol includes one station consisting of five people, one engine, and one ambulance. Upon stabilizing the victim at the scene, two certified personnel travel with the victim to either a site medical facility or an off-site hospital. While the tasks performed during emergency medical incidents are varied, analysis indicates the majority of the incidents can be managed effectively by this five person response. This is primarily due to the type facilities found at SRS and the amount of equipment which must be carried long distances where direct access to patients is not possible. When the EMS call is the second event (i.e. department personnel are already committed to mitigating a significant fire or haz-mat incident when the EMS call is received), EMS response will be one ambulance with two people until such time as additional personnel can be assigned by the Incident Commander.

\section{.5.3 Hazardous Materials Response}

The SRSFD provides hazardous materials response and mitigation services. Site hazard analysis identified the use and transportation of large quantities of hazardous materials which poses a substantial risk to site facilities, population and the environment when containment is compromised. The magnitude of hazardous materials incidents occurring at SRS may range from minor spills of environmentally hazardous substances to the release of toxic substances with the potential for affecting a large percentage of the site population and/or the local community.

The following table illustrates the approximate number of personnel required to perform hazardous materials entry operations for up to one hour based on tasks which must be performed by the regulatory requirements found in OSHA 29 CFR, 1910.120 and the Site Manual 20Q, Health and Safety for Hazardous Waste Operations.

Table 5.3

\begin{tabular}{|l|c|}
\hline \multicolumn{2}{|c|}{ Hazardous Materials Mitigation Task Analysis } \\
\hline Task Analysis & $\begin{array}{c}\text { Personnel Required To } \\
\text { Perform Task }\end{array}$ \\
\hline Entry Team -Level A or B & 4 \\
\hline Back-Up Safety Team & 2 \\
\hline Decontamination Team & 4 \\
\hline Safety Officer & 1 \\
\hline Operations Officer & 1 \\
\hline Tncident Commiander & 1 \\
\hline EMSTMedical Siurveillance & 2 \\
\hline Logistics/Science Officer & 1 \\
\hline Total Personnel: & 16 \\
\hline
\end{tabular}




\section{$5.4 \quad$ Technical Rescue}

A comprehensive technical rescue program is provided by the SRSFD. This program provides enhanced response capabilities in the following areas:

- $\quad$ Confined Space Rescue

- High Angle Rescue

- Building Collapse Rescue (e.g. earthquake, tomado, explosion)

- $\quad$ Trench Collapse Rescue

- Vehicle Extrication

SRSFD has developed a basic confined space rescue capability to the requirements of OSHA 29 CFR, 1910.146. The remaining areas, high angle rescue and building/trench collapse rescue are heavy rescue operations which must be provided due the range of hazards which have been identified on the site.

\subsubsection{Confined Space Rescue}

The response to confined space rescue is governed by OSHA 29 CFR 1910.146, Permit Required Confined Spaces. There are more than 2,000 permitted confined space entries at SRS annually. The following table illustrates the number of personnel required to perform confined space operations.

Table 5.4.1

\begin{tabular}{|l|c|}
\hline \multicolumn{1}{|c|}{$\begin{array}{c}\text { Confined Space Rescue Task Analysis for SRS Baseline } \\
\text { Incident }\end{array}$} \\
\hline Task Required & $\begin{array}{c}\text { PersonnerRequired To } \\
\text { Perform }\end{array}$ \\
\hline Entrant/Rescuers & 2 \\
\hline Backup Safety Team & 2 \\
\hline Safety Officer/fftendant & 1 \\
\hline $\begin{array}{l}\text { Personnel to operate supplied } \\
\text { air breathing systems, } \\
\text { ventilation systems and air } \\
\text { monitoring instruments }\end{array}$ & \\
\hline EMSTransport & 2 \\
\hline Incident Commander & 1 \\
\hline Total & 9 \\
\hline
\end{tabular}

- This number represents the minimum number of responders required to undertake a contined space rescues in atmospheres where chemical protective clothing is not required. For atmospheres requiring chemical protective clothing, the emergency operation would then fall under the guidelines of OSHA 1910.120 , thereby becoming a hazardous material response requiring decon for entry personnel (a minimum of 4 additional personnel).

\subsubsection{High Angle Rope Rescue}

The need for high angle rescue capabilities at SRS is clearly evident based on the height and configuration of many site facilities. The site currently has a number of multi-story buildings. A potential for incidents involving rope rescue operations exists in elevated structures including multi-level process buildings, multi-storied administration buildings, cooling towers, water tanks, and radio repeater towers. A typical rope rescue performed at SRS is elevator rescue (8-10 events annually). The table below illustrates the task commonly required by high angle rescue incidents and the corresponding number of personnel required. 
Table 5.4 .2

\begin{tabular}{|c|c|}
\hline \multicolumn{2}{|c|}{ High Angle Rescue Incident Task Analysis } \\
\hline Task Required & $\begin{array}{l}\text { Personnel Required To } \\
\text { Perform }\end{array}$ \\
\hline Rappel/Rescuers & 2 \\
\hline $\begin{array}{l}\text { Mechanical Advantage } \\
\text { System Operatiors }\end{array}$ & 2 \\
\hline Safety Officer & 1 \\
\hline EMS at Inciden IScene & 2 \\
\hline Tncident Commander & 1 \\
\hline Total PersonneT & 8 \\
\hline
\end{tabular}

- This is considered the minimum number of personnel required for a rescue incident which requires the raising or lowering of victims via mechanical advantage systems.

\subsubsection{Heavy Rescue Operations (Trench and Building Collapse Rescue)}

The site hazard analysis and classification sections of this report identified a definite need for heavy rescue operations capability at SRS. First, SRS has a very large number of temporary office facilities and administration buildings which are subject to collapse in the event of tornado or extremely high wind conditions, potentially trapping a large number of occupants. Heavy rescue capabilities do not currently exist in the surrounding communities. Environmental restoration and D \& D activities also create a potential need to provide heavy rescue capabilities at the site: NFPA 1470, Building Collapse Search and Rescue Operations does not specifically identify the number of responders needed for incident mitigation, but it does demonstrate the functions associated with this type operation. This standard requires the preparation of a risk assessment. This report fulfills this requirement. The tasks performed during trench rescue operations along with personnel required are shown in Table 5.4.3.

Table 5.4.3

\begin{tabular}{|l|c|}
\hline \multicolumn{2}{|c|}{$\begin{array}{c}\text { Trench anc/Building Collapse Rescue Incident Task } \\
\text { Analysis }\end{array}$} \\
\hline Task Required & $\begin{array}{c}\text { Personnel Required To } \\
\text { Perform Task }\end{array}$ \\
\hline Shoring Operations & 4 \\
\hline Primary Rescuers (EMS) & 2 \\
\hline Safety Officer & 1 \\
\hline Logistics Team & 2 \\
\hline EMS at Incident Scene & 2 \\
\hline Incident Commander & 1 \\
\hline Total Personnel & 12 \\
\hline
\end{tabular}

"A building collapse would require similar functions, but would require more personnel for tasks such as rubble removal, EMS, etc.

Heavy rescue operations at the scene of trench or building collapses involves very methodical and labor intensive tasks. The number of responders required will depend largely on the extent of operations to be conducted. The need to provide heavy rescue operations capabilities to the site is established by several factors including facility construction and occupancy capacity, excavations for construction and large scale utility systems upgrades as well as the projected scope of environmental restoration activities. 
These factors are not easily changed, safeguards are used to minimize the number of incidents which occur but can not eliminate the potential for heavy rescue incidents.

\subsubsection{Vehicle Extrication}

The SRSFD routinely responds to vehicle accidents in which extrication capabilities are required. In most cases, staffing levels described previously in this report are adequate to effectively mitigate the incident and provide timely patient care. However, the potential exists for a multi-vehicle, mass-casualty accident in which initial response resourceis could be stressed, and the EMS resources could be depleted very quickly. The response and call-back of off-duty forces would be similar to those previously described and would rely heavily on mutual aid from surrounding community ambulance services.

\subsection{Simultaneous/Signilicant Incident Supplemental Staffing Protocol}

Proposed staffing levels may increase based on credible scenarios in unprotected (nonhighly protected risk) facilities. The increase in staffing levels for these special instances may be accommodated by the dispatch of the entire shift compliment to the scene, with rapid call back of off-duty personnel after initial size-up and the use of mutual aid agreements with surrounding, communities.

The fire department has developed supplemental staffing protocols which will be utilized to augment shift personnel cluring large scale incidents. Supplemental staffing for large scale incidents will be provicled in the following manner:

- Call back of off duty personnel via all-call page.

- Activation of mutual aid agencies.

When appropriate, the Battalion Chief on shift will initiate the SRS Fire Department "All Call". This system includes procedures in the SRS Operations Center (911 Center) and pagers issued to all SRSFD piersonnel. The Battalion Chief has two options, recall of one shift and recall of all off duty SRSFD personnel. Assuming a $50 \%$ response, these options would provide 9 personnel and 30 personnel, respectively. Personnel would respond to their "home" fire station, secure personal protective equipment, and proceed to a staging area. Response times for these personnel vary widely but are assumed to be initial responders in 30 minutes from all call, one engine with 5 personnel in 45-60 minutes from all call, and full force availability in 90 minutes. This force can sustain the attack on large, sophisticated responses and will relieve the on-shift force.

A second option is also available - mutual aid. The communities which surround the SRS have primarily volunteer fire departments. Aiken County EMS, Aiken Rescue Squad, and Jackson First Alert have ambulances near the site which can also respond. The Aiken County Haz-Mat Team is also available. Mutual aid is available at all times with variable response times. Mutual aid provides three vital capabilities:

1. Backup ambulance.

2. Structural firetighting for non-nuclear facilities.

3. Multi-function team support for all facilities as needed. 
The backup ambulance is generally available in 40-60 minutes from request. An engine company is generally available in the same time period with additional engine companies available on a slightly extended schedule. Three engine companies could be available in 90 minutes. Additional joint training and drills will be necessary to ensure adequate integration with mutual aid for all these functions.

The table below describes the force availability for a SRS emergency to support the Fire Department. Significant numbers of other personnel are available to support other aspects of an emergency response.

\section{Table 5.5}

\begin{tabular}{|c|c|c|c|c|}
\hline \multicolumn{5}{|c|}{ Supplemental Staffing Resource Response Time } \\
\hline Time & $\begin{array}{l}\text { Minimum } \\
\text { SRSFD Shift } \\
\text { Staff }\end{array}$ & FD All-Call & Mutual Aid & Total \\
\hline $\begin{array}{c}T+20 \\
\text { minutes* }\end{array}$ & 78 & 0 & 0 & 18 \\
\hline $\begin{array}{c}T+50 \\
\text { minutes }\end{array}$ & 78 & 2 & (1 Ambulance) & 22 \\
\hline $\begin{array}{c}T+80 \\
\text { minutes }\end{array}$ & 78 & 5 & $\begin{array}{c}\text { (1 Ambulance } \\
1 \text { Engine) }\end{array}$ & 30 \\
\hline $\begin{array}{l}1+110 \\
\text { minutes }\end{array}$ & 78 & 24 & $\begin{array}{c}17 \\
\text { (1 Ambulance } \\
3 \text { Engines) }\end{array}$ & 59 \\
\hline
\end{tabular}

$T+20$ assumes 20 minutes from receipt of alarm to attack by SRSFD force.

** The mutual aid force could include more ambulances and fewer engines if desired

- this is an illustration of one force structure.

Additionally, SRS operational nuclear facilities also train their personnel for emergency response, to complement the Fire Department. Facility personnel are generally immediately available for logistics, facility entry support, and transportation duties (i.e. transport of walking wounded). Use of these forces in support of the Fire Department is being proceduralized, initially as a test in the HB-Line.

\subsection{Collateral Duties}

In addition to providing emergency response services to the site, the SRSFD performs inspections and basic maintenance services for a large percentage of the fire protection components at the Savannah River Site. These activities are illustrated in the chart below.

Table 5.6

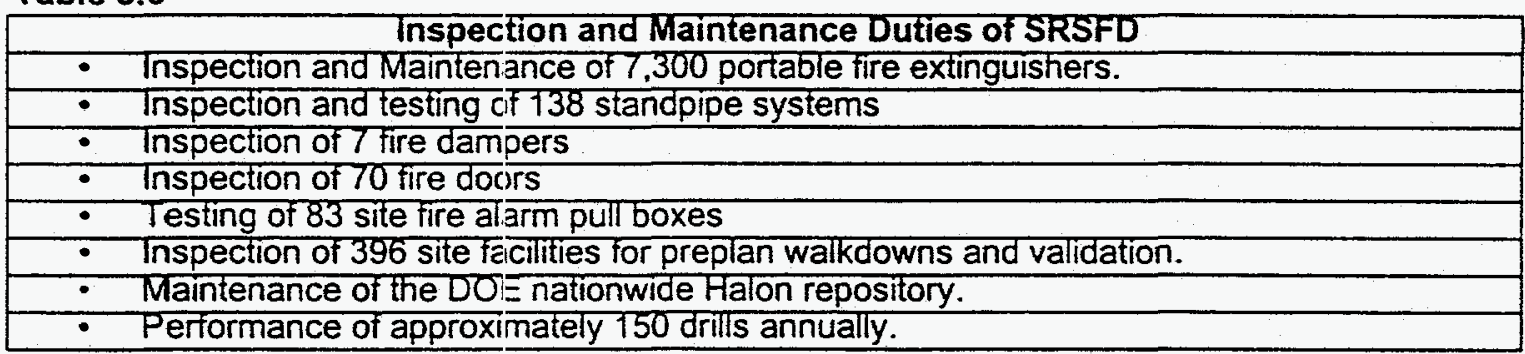




\subsection{Staffing Analysis Summary}

To meet the demands of current and future SRS missions, fire department staffing must be sufficient to respond to and successfully mitigate the baseline emergency incidents established through site hazard analysis. The population of the site and the types of facilities found at SRS clearly indicate the need to maintain an offensive emergency response posture.

The approach used to determine staffing needs for the SRSFD exercised sound engineering analysis and operational experience. Detailed operational experience data may be found in SRSFD annual reports. The baseline incidents for each mission, as well as applicable NFPA, OSHA and DOE regulatory requirements and accepted industry practices determine the number of personnel required to carry out operations. The most influential baseline incident in determining staffing strength for the fire department is a fire incident requiring a fire llow of up to $400-500$ gallons per minute, forcible entry, and search and rescue (See Table 5.7).

Task analysis for the baseline incidents demonstrates the need for a minimum of sixteen personnel to respond to the scene of baseline incidents. In addition, based on frequency and duration data for Emergency Medical Services (EMS) responses, the capability must exist to handle a simultaneous EMS event somewhere else (such as a patient being transported to an offsite hospital) while still providing an ambulance at the baseline incident scene to provide coverage for possible injuries or victims. This second EMS event requires two personnel available to respond to the EMS incident. The following table summarizes the overall. total proposed minimum staffing based on the incidents previously described:

Table 5.7

\begin{tabular}{|l|c|}
\hline \multicolumn{2}{|c|}{ Task Analysis Minimum Staffing Summary } \\
\hline Task Required & $\begin{array}{c}\text { Personnel Required To } \\
\text { Perform Task }\end{array}$ \\
\hline Charge and Advance Attack Lines & 4 \\
\hline Rapid Intervention Crew & 2 \\
\hline Search and Rescue & 4 \\
\hline Apparatus Operator & 2 \\
\hline Safefy Officer & 1 \\
\hline Incident Commander & 1 \\
\hline EMS at Incident Scene & 2 \\
\hline Total Personnel: & 16 \\
\hline 2ndlncident (EMS) & 2 \\
\hline Total Proposed Staff: & 18 \\
\hline
\end{tabular}

With the above staffing, the SRSFD can mitigate baseline incidents in all facilities while retaining capability to respond to a second EMS incident. Incidents in 3 facilities (703-A, SRTC, and F Canyon) will require response by the second EMS team to help mitigate the incident and mutual aid or call-back must be immediately initiated to provide for response to the second postulated EMS incident. There are other possible options to address the minimum SRSFD staffing requirements. These options include:

- Install fire protection upgrades in $221-\mathrm{F}$, Canyon consisting of limited automatic sprinkler protection for cable trays with Fire Department hose connections on the sprinkler risers. This would reduce the quantity of hose required to be laid into $F$ Canyon, thus allowing firefighters to perform other duties. 
- Install fire protection upgrades in 773-A consisting of automatic sprinkler protection for the non-sprinklered areas in D-Wing (excluding the Fabrication Laboratory) and the 2 nd floor of A-Wing.

- Provide effective accountability for 703-A facility personnel. Personnel (e.g. Fire Wardens) leaving the facility would perform a quick sweep of areas not directly involved in the fire, thereby assisting the fire department with the primary search and rescue duties. (See 5.1.2.2, 703-A scenario description.)

- Establish protocols to provide additional response personnel. Innovative use of these personnel, such as SRSFD day shift staff and certified firefighters and fire brigade personnel from other site: organizations, could reduce assigned Fire Department shift staffing to less than 18 or could reduce the need for overtime if Fire Department staffing is 18. Also, in order to make effective use of the responding emergency service personnel, the facility OSC when activated can provide two facility support personnel to assist the SR.SFD.

\subsection{FIRE DEPT. APPARATUS \& EQUIPMENT REQUIREMENTS}

\subsection{Current Assessment of Existing Apparatus}

The Fire Department apparatas fleet is described below:

\begin{tabular}{|c|c|c|c|}
\hline Apparatus \# & Model & Pump Size & $\frac{\text { Scheduled }}{\text { Replacement }}$ \\
\hline $\begin{array}{l}\text { Engine \#1 } \\
\text { Engine \#2 } \\
\text { Engine \#3 } \\
\text { Engine \#4 } \\
\text { Engine \#7 } \\
\text { Forestry \#1 } \\
\text { RRT }\end{array}$ & $\begin{array}{l}1993 \text { E-One } \\
1990 \text { Central States } \\
1993 \text { E-One } \\
1979 \text { Fire-Tech (water supply) } \\
1993 \text { E-One } \\
1997 \text { Chevrolet } \\
\text { Rescue Response Trailer }\end{array}$ & $\begin{array}{l}1500 \mathrm{gpm} \\
1500 \mathrm{gpm} \\
1500 \mathrm{gpm} \\
750 \mathrm{gpm} \\
1500 \mathrm{gpm} \\
250 \mathrm{gpm} \\
\mathrm{NA}\end{array}$ & $\begin{array}{l}2008 \\
2005 \\
2008 \\
\mathrm{NA} \\
2008 \\
2004 \\
\mathrm{NA}\end{array}$ \\
\hline $\begin{array}{l}\text { Ladder \#1 } \\
\text { Tanker \#1 }\end{array}$ & $\begin{array}{l}1990 \text { Gnimman Aerialcat } \\
1986 \text { Intimational Tractor } \\
(5,500 \text { gallon tank) }\end{array}$ & $\begin{array}{l}1500 \mathrm{gpm} \\
\mathrm{NA}\end{array}$ & $\begin{array}{l}2005 \\
2006\end{array}$ \\
\hline HM \#1 & 1995 E-One Command Cab & NA & 2010 \\
\hline Boat \#1 & Boston Whaler & NA & NA \\
\hline $\begin{array}{l}\text { Rescue \#1 } \\
\text { Rescue \#2 }\end{array}$ & $\begin{array}{l}1992 \text { Ford } \\
1995 \text { E-One Command Cab }\end{array}$ & $\begin{array}{l}\mathrm{NA} \\
\mathrm{NA}\end{array}$ & $\begin{array}{l}2004 \\
2010\end{array}$ \\
\hline $\begin{array}{l}\text { Medic \#1 } \\
\text { Medic \#2 } \\
\text { Medic \#3 } \\
\text { Medic \#4 }\end{array}$ & $\begin{array}{l}1994 \text { Wheelcoach } \\
1994 \text { Wheelcoach } \\
1994 \text { Wheelcoach } \\
1994 \text { Wheelcoach }\end{array}$ & $\begin{array}{l}\text { NA } \\
\text { NA } \\
\text { NA } \\
\text { NA }\end{array}$ & $\begin{array}{l}2004 \\
2004 \\
2004 \\
2004\end{array}$ \\
\hline
\end{tabular}




\subsection{Apparatus Upgrades}

The SRS Fire Department apparatus fleet is adequate through the early 21 st century. As the replacement dates for apparatus approach, the department will evaluate and determine the most adequate way of replacement - either buying or leasing.

\subsection{Equipment}

Equipment improvements should focus on two aspects of the firefighting effort:

1. life safety of victims and firefighters and

2. suppression efficiency.

To this end SRSFD should conduct field evaluations of the below products and processes. Upon successful completion of the evaluation, SRSFD should acquire the appropriate processes or products, develop and implement appropriate training and incorporate their use in day-to-day operations.

1. life safety:

a. infra-red vision equipment.

b. positive pressure ventilation

c. automated acisountability system

2. suppression efficiency:

a. reduce nozzle reaction forces by use of low pressure nozzles and/or larger diameter lightweight hose.

b. use Class $\mathrm{A}$ foam to decrease required suppression flow rates.

c. portable delugge guns. 


\subsection{CONCLUSIONS}

The missions of SRS for the next five years do not significantly change the hazards that exist on the site. As a result, the role of emergency response forces is not significantly impacted. Analysis of the FDZs determined the SRSFD response levels across the site. Using this assessment, NFF'A codes and other applicable regulatory requirements the operational basis for the ernergency response forces at SRS is defined. In order to conduct the emergency respionse mission at SRS, the fire station locations, personnel plans, and apparatus must be considered.

\subsection{Fire Station Locations}

Fire stations must be strategically located so that resources are capable of arriving at the incident scene within an acceptable time. Sections 4.0 and 5.0 of this report determined the response levels for site FISZs and appropriate response times.

\subsubsection{Current Facilities}

The site is presently served by three fire stations. The table below shows the year constructed, the apparatus assignments, and the bay spaces at each station.

Table 7.1.1

\begin{tabular}{|l|c|c|c|c|c|}
\hline Station & Year & SRS Fire Station Configuration & \multicolumn{1}{|c|}{ Apparatus } \\
Assigned & $\begin{array}{c}\text { Apparatus } \\
\text { Storage } \\
\text { Capacity }\end{array}$ & $\begin{array}{c}\text { Stored in } \\
\text { Open }\end{array}$ & Issues \\
\hline$\# 1709-F)$ & 1954 & 6 & 3 & 3 & $\begin{array}{l}\text { Too old \& small, } \\
\text { poorly located to } \\
\text { support H, S \& Z }\end{array}$ \\
\hline$\# 2(709-A)$ & 1953 & 4 & 1 & 3 & $\begin{array}{l}\text { Too old \& small, } \\
\text { Poorly located to } \\
\text { integrate } \\
\text { response with } \\
\text { other stations. }\end{array}$ \\
\hline \#(709-1G) & 1989 & 5 & 5 & 0 & $\begin{array}{l}\text { Adequate in size } \\
\text { and design. }\end{array}$ \\
\hline
\end{tabular}




\subsubsection{Recommendations for Fire Station Replacements}

In order to meet the response time goals established by site hazard analyses and reduce emergency response times to the majority of the site facilities, fire stations must be strategically located. Locations should be chosen based on their proximity to FDZs with the greatest hazard ranking and population densities. The sites selected should also allow for a more even distribution of the emergency response call volume if possible.

\subsubsection{Fire Station \#1 (709-F)}

In FY-98 GPP funds have been allocated to construct a new fire station. Building a new Station $\# 1$ at Roads $C \& 5$ has been recommended by the Project Management Team biased on cost benefit analysis of various candidate locations. This team concurs with building the new station but recommends that the selected location provide for efficient response to all areas within the response zone; provide a facility better suited to house equipment and personnel; and reduce response times to $\mathrm{H}, \mathrm{S}, \mathrm{Z}$ and ITP Areas.

\subsubsection{Fire Station \#2 (709-A)}

A new fire station has been designed but is not funded in FY-98. Funding has been requested for FY-99. Building a new Station \#2 in B Area has been recommended by the Project Management Team based on cost benefit analysis of various candidate lociations. This team concurs with building the new station but recommends that the selected location provide for efficient response to all areas within the response zone; provide a facility better suited to house equipment and personnel; and reduce response times to Forestry, D, T, and B Areas.

\subsubsection{Fire Station Location and Response Time Summary}

The distribution of fire stations, in particular Fire Station \#1, should be improved to optimize response times. Originally site fire companies were considered somewhat independent, responding as a single element. The DOD guidance offers a more realistic approach to fire company location considering the amount of resources required to effectively control fire and various other emergency incidents. The response time guidance set forth by DOD is concurrent with the types of facilities at SRS and the inherit hazards of the facilities. As stated previously in this report, response time to site emergencies should be minimized to the greatest degree possible. The SRSFD must assure that emergency response forces are distributed based on the response level assignments for site FDZs and the demand for emergency service delivery to the sile.

The adoption of response time requirements in this document which are commensurate with the risks of the site has an overwhelming effect on the success of emergency incident resolution. By minimizing response times to site facilities based on the degree of risk present resources required to manage incidents are also lessened. Therefore, 
when response times are increased so is the potential for greater property loss or loss of life from an emergency incident.

Two of the fire stations presently serving the site are in need of extensive renovation or replacement. Cost estimates for these renovations to meet NFPA codes show that the most cost effective way to improve the stations is to construct new stations which better suit site emergency response needs at lower costs. The third fire station (709$1 G$ ) will continue to serve the reactor areas through decommissioning and eventual demolition activities. The engine company located in this station will also support other response forces across the site.

SRS fire stations must be positioned to ensure that, for Authorization Basis Document based fires, all required fire flow is capable of being delivered within approximately 20 minutes of alarm receipt at the Operations Center (911 Center). In addition, stations should be distributed to provide EMS response within 8 minutes across the site. This means that fire stations should be located near A/B Area and the F/H/S Areas because these areas are the most densely populated and contain the highest hazards.

\subsection{Staffing Levels}

The proposed staffing available to respond to site incidents is defined as eighteen personnel based on an analysis of incident scenarios in the more hazardous structures (those requiring Level 1 response) and includes sixteen personnel to respond to the baseline incident scenario (14 firefighters and 2 EMS responders) and two EMS response personnel available for a postulated simultaneous EMS event. The 18 responders may be SRSFD on shift personnel, SRSFD day shift personnel, certified firefighters from other site organizations, or structural interior fire brigade personnel. Additionally, the three non-baseline incidents can presently be mitigated by responding all 18 personnel. Additional fire protection upgrades in 773-A and 221-F as well as the establishment of effective personnel accountability in 703-A will reduce the staffing requirement in these facilities to the baseline of 16 responding personnel. In these cases, mutual aid or callback of off-duty personnel would be required to make another EMS unit available for the postulated second EMS event.. (See section 5.1.2 and particularly 5.7.)

A series of four (4) drills emulating the non-baseline SRTC AB Document based fire have been conducted. Each drill involved a different fire department battalion responding to the same scenario. Consensus was reached among DOE, SRSFD, and FPPD that 18 persons available to respond on shift is a reasonable staffing level.

Furthermore, when a response shift drops below the minimum staff number, SRS cannot be assured of adequate capability onsite to respond to a postulated baseline incident. However, the proposed staffing level does not ensure any capability to respond to multiple incidents except possibly in the EMS area of responsibility.

If it is determined to staff fully with Fire Department personnel, there should be additional firefighters assigned to the shift. This is to accommodate absences due to vacation, disabilities, special task assignments, etc. During times when firefighters above the 18 minimum are on duty, the Fire Department will be able to respond to some types of simultaneous incidents. 


\section{APPENDIX A - SUPPORT PROGRAMS}

\subsection{SUPPORT PROGRAMS}

\subsection{Training Programs}

The Savannah River Site Fire Department provides training to the operating shifts during scheduled training hours in the four shift rotation. Training topics are developed and delivered by a qualified training staff in each of the service areas provided by the SRSFD. Topics are outlined to meet applicable NFPA requirements for Firefighter Level I and II, Hazardous Materials Technician as well as SCDHEC for In-Service Emergency Medical Certification. The SRSFI) is also an external provider for the U.S. Environmental Protection Agency (EPA) Course "Emergency Response to Hazardous Materials Incidents".

Additionally, the training division coordinates scheduling of Fire Department personnel to comply with site specific requirements for:

- $\quad$ Consolidated Annual Training (CAT)

- $\quad$ Radiation Worker I and II (RadWorker I and II)

- $\quad$ General Negative Pressure Respirator Training

- $\quad$ Facility Specific Entry Training.

Furthermore, the SRSFD training division has implemented a number of substantial costsaving initiatives and at the same time has continued to up-grade the existing programs in an effort to provide a developmental basis for skill improvements. For example, the SRSFD is now able to certify all members of the department at the hazardous materials technician level due to the certification as an external provider of EPA's Emergency Response to Hazardous Materials Incidents. This program has been made available to other site organizations surch as Industrial Hygiene, Wackenhut Services Inc. (WSI), Emergency Preparedness, and Transportation as well as to industries and fire and EMS providers in surrounding communities.

\subsection{Training Program Dbjectives for FY '97-'98}

In addition to the training programs currently offered by the SRSFD, specific training objectives have been identified by the department for fiscal years '97 and '98. These programs will allow the fire department to continue to support site emergency service demands while providing fire department personnel with specialized training at minimal costs to the site.

Major Training Objectives for FY '97-'98:

- Implementation of the International Fire Service Accreditation Congress certification program. This program will provide personnel with national certifications in various fire service occupational disciplines.

- Conduct live fire training, rescue and hazardous material training programs. 
- $\quad$ Provide initial and annual refresher EPA "Emergency Response to Hazardous Materials Incidents" to all Fire Department personnel and other site organizations as needed.

- Continue to enhance the technical rescue program to meet requirements of NFPA 1470, "Standard on Search and Rescue Operations for Structural Collapse Incidents, Advanced Rope Rescise Operations and Confined Space Rescue Operations."

- Enhance the training program for off-site agencies detailing the requirements for mutual aid responses to the SRS.

\subsection{Physical Fitness Program}

\subsubsection{Medical Surveillance}

All firefighters are subject to an annual physical examination based on the requirements established by NFPA 1001, 1582 and 1500. This program is administered by Site Medical and includes a comprehensive medical exam.

\subsubsection{Current Fitnesis Program}

The current physical fitness training program was adopted based on the fitness requirements found in NFPA 1500,1992 ed. This program measures overall fitness of department personnel based their performance in the following areas administered in the annual fitness test.

$\begin{array}{ll}\text { - } & \text { Bruce Protocol Treadmill Test } \\ \text { - } & \text { Push-ups } \\ \text { - } & \text { Fit-ups } \\ & \text { Blexibility - Sit \& Reach } \\ & \text { Balance Walk } \\ \text { - } & \text { Grip Strength } \\ & \text { Body Fat Percentage }\end{array}$

10 minutes, 05 seconds

25

35 in two minutes

Past toes

Walk $20^{\prime}$ beam with a $20 \mathrm{lb}$.

weight.

$100 \mathrm{lbs}$.

Male:

Below $25 \%$

Female: $\quad$ Below $31 \%$

\subsection{Community Assistance Training}

SRS's strong emergency response training program is also offered to the community as circumstances permit. This training strengthens the local community's ability to provide effective mutual aid to SRS and therefore also serves a valuable site mission. During October and as requested, the SRSFD gives fire safety talks at local public schools. This program affords a tremendous opportunity to educate children on fire safety and further reinforces a positive image of the department as a needed service provider.

Moreover, the department attempts to assist surrounding communities in providing educational opportunities for area emergency response personnel. For the past two years, Westinghouse Savannah River Company through the SRSFD has been the industrial sponsor for the Annual Aiken County Fire School. The company has provided classrooms, equipment, consumables, training props, instructors, and the training ground areas to the Aiken Co. Firemien's Association, who sponsors the school, to be used as needed. In conclusion, the department also provides the EPA course, "Emergency Response to Hazardous Materials Incidents", to local fire, EMS and law enforcement personnel as space is available. 


\section{REFERENCES}

1. Approval of Standarcls/Requirements Identification Document (S/RID) Functional Area 12, "Fire Protection" (Letter, Schwallie to Fiori, ESH-EMS-960257, 9/30/96).

2. Department of Defense, Department of Defense Fire Protection Program, Number 6055.6, June 10, 1981 .

3. Department of Energy Order 420.1, "Facility Safety".

4. Department of Energy Order 440.1, "Worker Protection Management for DOE Federal and Contractor Employees".

5. Engineering calculation S-CLC-G-00151 "Authorization Basis Fire Department Functional Requirements".

6. Implementation Guide for Use With DOE Orders 420.1 and 440.1, Fire Safety Program, September 30, 1995.

7. Insurance Services Office, "Fire Suppression Rating Schedule", 1990.

8. International Association of Fire Fighters, "Safe Fire Fighter Staffing - Critical Considerations," 1993.

9. International City Management Association, Managing Fire Services, Second Edition (Washington, DC) 1988.

10. National Fire Protection Association, Fire Protection Handbook, 18 th Edition, 1997.

11. National Fire Protection Association, NFPA 1200, Standard for Organization, Operation, Deployment, and Evaluation of Public Fire Protection and Emergency Medical Services, DRAFT, 1998 Edition.

12. National Fire Protection Association, NFPA 1201, Developing Fire Protection Services for the Public, 1994 Edition.

13. National Fire Protection Association, NFPA 1410, Training Standard on Initial Fire Attack, 1988 Edition.

14. National Fire Protection Association, NFPA 1470, Search and Rescue Training for Structural Collapse Incidents, 1994 Edition.

15. National Fire Protection Association, NFPA 1500, Standard on Fire Department Occupational Safety Health Program, 1992 Edition.

16. Professional Loss Control, Inc., "Analysis of the Savannah River Site Fire Department", 1988.

17. Professional Loss Control, Inc., "Updated Analysis of the Savannah River Site Fire Department", 1992. 
18. "Programmatic Guidance for Fiscal Year 1998" - Shrine.

19. Savannah River Site Fire Department, Fire Control Preplans - Manual 2Q2.

20. Shipment Mobility / Accountability Collection System, Summary for April 1, 1995 to March 31, 1996.

21. United States Departrnent of Energy, "DOE Interpretations Guide To Occupational Safety and Health Standards", Interpretations 93033001 and 93060201.

22. United States Departrnent of Energy, DOE Order 6430.1A, Section 1530-2.3.5.

23. United States Departrnent of Energy, "Emergency Response Organization Review Criteria for DOE Field Elements", Draft 1994.

24. Unites States Department of Labor, OSHA 29 CFR 1910.120, Hazardous Waste Operations and Emeryency Response, 1989.

25. United States Departrnent of Labor, OSHA 29 CFR 1910.146, Permit Required Confined Space Entry' Standard.

26. Westinghouse Savanrah River Company, Savannah River Site Five Year Plan (U): Executive Summary. 